Article

\title{
Framework Conditions and Strategies for Pop-Up Environments in Urban Planning
}

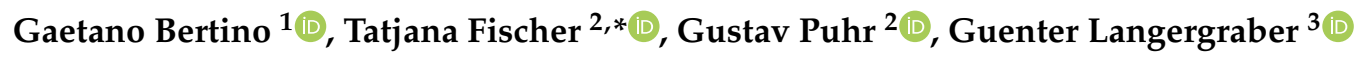 \\ and Doris Österreicher ${ }^{2}$ (1)
}

1 Alchemia-Nova GmbH, Institute for Innovative Phytochemistry \& Closed Loop Processes, 1140 Vienna, Austria; gaetano.bertino@alchemia-nova.net

2 Department of Landscape, Spatial and Infrastructure Sciences, Institute of Spatial Planning, Environmental Planning and Land Rearrangement, University of Natural Resources and Life Sciences, Vienna (BOKU),

A-1190 Vienna, Austria; gustav.puhr@boku.ac.at (G.P.); doris.oesterreicher@boku.ac.at (D.Ö.)

3 Department of Water, Atmosphere and Environment, Institute of Sanitary Engineering and Water Pollution Control, University of Natural Resources and Life Sciences, Vienna (BOKU), A-1190 Vienna, Austria; guenter.langergraber@boku.ac.at

* Correspondence: tatjana.fischer@boku.ac.at; Tel.: +43-1-47654-85517

Received: 30 September 2019; Accepted: 11 December 2019; Published: 16 December 2019

\begin{abstract}
Urban strategies and the way cities are planned have changed throughout history, adapting to the needs of the inhabitants, infrastructure requirements, and advances in technology. Uses and customs of people and cities are changing and can evolve much faster than in the past, with the result that urban planning is often too slow to adequately meet the current needs of society. In this context, the development of pop-up environments for temporary developments could be a solution to meet the needs of flexibility, adaptation, and resilience of a city. This allows the urban planner to consider systems from a short-term perspective, fulfilling current needs without compromising the development of potentially different activities in the future. The purpose of this research work is to outline the general requirements of pop-up environments in urban developments that allow for adequate integration into urban planning strategies. Based on an extensive evaluation of the existing literature and a series of case studies, the paper analyzes the key elements that define the framework conditions of urban planning strategies for temporary developments that generate a positive impact on the overall urban system.
\end{abstract}

Keywords: pop-up environment; temporary architecture; pop-up housing; temporary use; temporary strategies for urban planning; sustainable planning; urban planning

\section{Introduction}

Since the industrial revolution, humanity has witnessed the development of remarkable scientific and technological progress, with an exponential acceleration of production processes and technology comparing it to the fairly linear trend of previous centuries. It has transformed city spaces, changing drastically the nature of the social relationships that were woven into these spaces [1]. The concentration of the population in urban areas, the process of transforming the territory from rural to urban, and the development of inhabited centers were the basis of the urbanization process of the territory, with the creation of new cities and the expansion of existing ones, in a process continues today and is likely to continue in the future [2].

The way of life in big cities evolves much faster than in the past and is indirectly reflected in modern urban planning, a discipline based on the production of results that contribute to temporal benefits without limiting the form and the functions of the city in the future [3]. Urban planning aims to 
integrate the individual parts of the city within a broader context, with the inclusion of an analysis on a temporal basis, trying to foresee the future changes in the society's way of living in a way that does not compromise the possibility of adaptation to different urban models for the following generations $[3,4]$. Unfortunately, getting results is not easy: if citizens' habits and customs evolve too quickly, how can city development occur at the same speed? How can a "mismatch" between the constantly evolving city and urban planning struggling keeping up with changes in user needs over time be avoided?

In this framework, the present research study aims at finding potential answers to these questions through the use of pop-up environments (PUEs), intended as structures or objects conceived from the outset as temporary, based on characteristics such as flexible light-weight technologies, fast and easy assembly, temporary occupation of the ground, and adaptability to different uses, needs, and users. Temporary pop-up environments, known for cheaper, short-lived, and small-scale developments, could present alternatives to fill the gaps left by unsuccessful urban planning policies [5], as the current urban planning tools often fail to address and guide urban changes and lead to the decay of social infrastructure, public space, and civic identity [6]. Therefore, the temporary nature of pop-up environments would allow urban planners and architects to plan city development not only with a long-term perspective but also in the short term, envisaging the creation of structures that meet the current needs of the community, without compromising the future development of activities or infrastructures with different functions. The use of pop-up environments offers the opportunity to study unconventional solutions and experiment with functions, allowing quick and flexible answers and circumventing some bureaucratic planning procedures [7]. Today, pop-up environments are being increasingly implemented in city development projects and sometimes are also used as urban planning tools in cities. During the last few years, public authorities' attitudes toward temporary uses have changed markedly [8], going from being an obstacle to urban planning [9] to being accepted and even implemented as an urban strategy in certain cases [10]. Additionally, it is now common to see temporary pop-up housing projects involving accommodation for students, tourists, workers, migrants, and low-income families $[7,10,11]$.

The aim of this research paper is to outline how pop-up environments can be an integrative tool for urban planning and how their use can be a temporary solution to issues often affecting cities, without compromising any future permanent use. When defining what a pop-up environment is from an architectural and urbanistic point of view, the features typically presented and the general requirements to be met in its use have been framed. The analysis of the key points in common for the realization of temporary pop-up environments has led to the notion of general architectural criteria that can be applied in the most diverse contexts, being the basis for future implementations to respond specifically to the needs of a diverse group of citizens. The comparison of different case studies allowed for an analysis of the contribution of pop-up architecture for city planning, in contexts typically difficult to tackle with the tools of traditional urban planning, such as vacant plots and empty abandoned buildings too expensive to be refurbished or high density urban areas where morphologic barriers and legal limitations do not allow for the realization of new infrastructure. By evaluating whether and how these examples met the required expectations in compliance with the principles of economy and sustainability, this paper analyzes the contribution of pop-up environments to urban planning. It is proposed as an initial study for laying the groundwork for subsequent future studies on the subject, as to date, there is only limited scientific documentation available on this subject.

The present paper is part of the the-year research project "Urban Pop-Up Housing Environments and Their Potential as Local Innovation Systems" funded by the Vienna Science and Technology Fund (WWTF). The aim of the project is to research urban systems in a comprehensive, holistic, and interdisciplinary manner, contributing to the development of sustainable urban living environments in order to prepare the ground for temporary housing concepts and solutions as local innovation systems. The project focuses on the investigation and evaluation of existing temporary housing options and the creation of innovative models of pop-up living systems in urban environments. A scientifically based guidance for living spaces, conceptualized as micro-innovation systems and 
sustainable, innovative, and high-quality "pop-up" housing forms, will be available at the end of the project [12].

\section{Background}

Aiming to highlight the framework conditions of the topic, this section is a preliminary background study. First, the city was analysed from a historical-urbanistic point of view in order to understand how the way of conceiving and structuring the city has changed. Urban planning is a constantly evolving and fluctuating discipline and must keep up with the speed of technological innovation by adapting new models of planning tools and innovative architectures. This is precisely the context in which pop-up environments should be inserted.

Second, the term "pop-up environment" will be clarified. Through the literature review, it appears clear that this topic has still not been studied extensively. The search settings using the keyword "pop-up" (used individually and in combination with "environments," "architecture," "housing," and "living system") produced only a few results [13-25]. As evidence of this, it can be pointed out that there is no general definition of what "pop-up" actually means. Addressing the terms "pop-up environments" and "temporary use" will be the base to define and provide fundamentals for the comprehension of PUEs in urban planning.

\subsection{Urban Planning in Continuous Transformation}

Urban planning is the discipline that studies the anthropized territory with the purpose of planning, reorganization, rehabilitation, and functional adaptation of already existing urban aggregates and the design of new aggregates. It aims at respecting people's customs, taking into account the characteristics of the city and the urban needs of its users, the feasibility and materiality assessments, the history that determined the current territory, the repercussions in the processes of social cohesion, and the constitutive rules of the shape of the city [26-28]. Piccinato defines urbanism as the general study of the conditions, manifestations, and necessities of the life and development of cities [21]. The practical purpose of urban planning aims at dictating the rules for the organization and functioning of an urban life that is beautiful, healthy, comfortable, and economical. Urban planning in general therefore looks at the evolution of the city as a whole, since the city can be considered as a living being in continuous transformation [29].The mutability of urban planning can be seen in the history of the cities, where it is possible to find various examples of how city growth has changed in the face of the different uses and customs that have occurred over time. The urbanization process of cities, in fact, is strongly conditioned by the relative socio-political conditions, and when these conditions change, those changes are reflected in urban planning. Below, some of the crucial moments in the development of urban planning will be analyzed in order to show how urban planning has changed in the past according to population needs and socio-political transformations.

The need to have an urban settlement in which a community concentrates specific activities was born in the Neolithic era, when the development of agriculture led to abandoning nomadic habits and necessitated a complex social organization and a stable settlement. Subsequently, a veritable urban revolution led to the birth of the first cities in fertile areas, along large rivers and vast agricultural plains, or in points that encouraged craft and commercial activities. The choice of the ideal place, the most suitable type of terrain, and its position with respect to the surrounding were essential elements for identifying the human space to be delimited [30]. The most important examples are found in Mesopotamia, with the development of cities along the rivers Tigris and Euphrates, and in Egypt along the Nile. There was not yet a clear and intentional spatial arrangement, but there was progress toward a development of the city in an irregular manner considering criteria of defensibility and food sustainability.

The first urban plans of certain origin date back to classic age, with Greeks first, and then Romans and Arabs, developing a model of urban planning with an orthogonal layout, although influenced by the territorial morphology, with some differences depending on different cultural aspects. In the Greek 
world, main and secondary roads (plateiai and stenopoi) divided the space into regular quadrangular blocks (strigae), while the functional center of the city (agora) was in a decentralized position on high ground (acropolis) [31]. In a scheme lacking a center integrated in the orthogonal grid, the individual areas had an equivalent importance, and in this, the desire to "democratically" plan the city is understood, thus respecting the liberal customs of the Greek world [31]. Romans further developed this model on the conformation of the military camp (castrum). Cities were designed upon two principal axes-the cardus maximus, a road with a north-south orientation, and the decumanus maximus, with east-west orientation. At their intersection stood the functional center (forum) [32]. The shape of the city was generally quadrangular, and the application of the scheme was rather flexible, adapted to the conformation of the places [33]. Romans applied physical planning principles and portrayed planning as an instrument of power, and the new-born cities were an expression of the Roman expansionist policy [34], aiming at the full control of the territory. The principles of the Greeks and Romans are reworked by Arabic urbanism, which follows the orthogonal division while introducing elements characteristics of their own culture, such as market streets. They, the true vital centre of every settlement, were the object of meticulous organization of the activity spaces, contributing significantly to the definition of urban identity [35] — even the caliphate palace and the mosque were placed along the main market road, which was significantly directed toward Mecca [35]. Arab urbanism developed through a territorial and demographic expansion that involves the assimilation of more ancient urban cultures $[35,36]$.

In the Middle Ages, the construction of cities was mostly a feudal initiative on high-altitude settlements that provided a strategic defensive advantage in the event of an attack. Perhaps also due to the morphological conformation of the rise that led to a circular perimeter, radial urban schemes developed around the lord's castle, with a concentric road system in which houses and shops were distributed. The urban plan assumed an organic character, following the irregularities of the elevation contours [37]. Between the 13th and 14th centuries, in order to resettle and control areas not yet urbanized, new urban centers arose, with the orthogonal layout again imposed, albeit with considerable variations [38]. The cities were affected by a process of expansion outside the ancient city walls, which led to the construction of new outer walls in a cycle that often had to be repeated [39]. The idea of giving the city an orderly and rational shape slowly matured in the works of the Renaissance [40] and even gave birth to the idea of the "ideal city," conceived of as a city whose urban design reflects the principles of rationality and a scientific approach [40]. Unfortunately, urban achievements between the 15th and 16th centuries were quite far from the theoretical frameworks, although they were equally characterized by the desire to determine spatial relationships through rigid models of centrality-radial convergence and axial alignment. These characters were connected to representative needs and to the centralization of power in the figure of the "Lord," who also determined the urban definition of "his" city [41].

It was after the advent of the industrial revolution, and the consequently impetuous and disorderly urban growth of the cities, that urban planning became a topic of discussion [42]. The industrial revolution triggered various socio-economic dynamics such as the increase of agricultural yields, the progress in the hygienic and sanitary field, and the massive arrival of people from the countryside who sought work in city factories [43]. These dynamics, combined together, caused a rapid demographic growth of the population [44] and consequently the transformation of the city that changed its appearance considerably with the advent of industrialization. In the old European cities, the major changes consisted of the uncontrolled expansion of unplanned suburbs that overwhelmed the traditional image of the city enclosed within the perimeter of the walls. They were torn down, because of their obsolete defensive function, to make room for productive buildings and infrastructure, such as railways and major roads. In an attempt to curb uncontrolled urban expansionism in the last decades of the 19th century, urban planning in the modern sense of the term began to be recognized as an autonomous discipline. Large-scale urban projects were planned, sometimes including the demolition of entire neighborhoods, to make room for areas rebuilt according to more rational urban schemes and 
responding to more modern and functional canons. Among the most noteworthy interventions of urban renewal are those of London (1848-1865) for the construction of the collectors along the Thames and the new underground line, Paris (1853-1869), and Brussels (1867-1871), with the demolitions, sought respectively by Haussmann and Anspach, of the old quarters for the construction of wide boulevards that extend outward beyond the limits of the old city, and Vienna (1857), where the so-called "ring" was constructed, namely a wide tree-lined artery that surrounds the entire medieval core, which has become the founding element of the city's structure.

From its 19th century origins to current times, the scope of planning has expanded dramatically [45]. Urban planners study, plan and design past, present and future scenarios of the city, as well as dealing with policies as well as technical and legislative regulations, in order to improve urban quality (in the broadest sense) and therefore the life of citizens. Today, the needs of citizens have become much more flexible and mutable than in the past, changing over time due to different factors, like in the "liquid society" mentioned by Zygmunt Bauman [46]. Technological innovations affect changes in customs and way of life with an emerging need of new infrastructures, new land uses, and new space availabilities. Unpredictable events, such as natural disasters like earthquakes and floods, lead to emergencies and the subsequent need for new housing solutions that are affordable and flexible but also sustainable and reusable, easy to construct, and rapid to implement $[47,48]$. New technologies have made new levels of migratory currents possible - the diffusion via TV of different living conditions and the growth of education in developing countries are among the factors triggering migrations, alongside wars, persecutions of various kinds, and hunger. The greater ease of transport [49] also results in migration being much easier than in the past. Finally, the consequences of human impact on the environment has resulted in the desire to create a sustainable future that concerns the whole city, in which the exploitation of resources, the investment plan, the orientation of technological development, and the institutional changes are all in harmony in order to meet needs and aspirations of its citizens [50].

In this context, a necessary aspect for modern urbanism is evident. Urban planning must be a flexible discipline that adapts to the characteristics of the city and meets the needs of users, bearing in mind that these properties evolve over time. This leads to replacing a "lasting" architecture with a "durable" and "temporary" architecture, designed to have a life related to the time when, presumably, it will be used. New methods are needed for the development of cities that are flexible in time and do not become a limitation to future urban growth, keeping pace with new market demands, while large-scale interventions, subjected to lengthy bureaucratic and implementation procedures, risk being overturned even before they are completed because, in the meantime, the boundary conditions that alter the initial assumptions have already changed.

\subsection{Pop-Up Environments and Framework Conditions}

"Pop-up" is a fairly new concept that has not yet been studied much, as can be seen from the scarcity of sources in scientific literature and the lack of a universal definition [24]. According to the Cambridge Dictionary [51], the term "pop-up" is defined as a verb ("to appear or happen, especially suddenly or unexpectedly"), as an adjective ("used to describe something that appears suddenly, and usually exists for a limited time"), and as noun ("a shop, restaurant, etc. that operates only temporarily for a short period when it is likely to get a lot of customers") [52]. From this definition, it emerges immediately that the term describes a temporary activity that can refer to different events and situations, generally including a series of contexts concerning architectural, artistic, economic, and social aspects. Combining the terms "pop-up" and "environment," the whole is given a physical form, which can assume different appearances-three-dimensional objects such as an architectural structure, an open space equipped with some facilities, or an artistic installation that emerge quickly and is designed to use a space temporarily [24].

If the keywords of the "pop-up" group led to few results, more results were found using the keyword "temporary" (used in double resulting combination first with words such as "strategies," 
"housing," "architecture," "uses," "structures," and "urban planning"). The results can be grouped in the following categories: temporary housing, in the context of emergency or to respond to new demands [47,48,53-69]; temporary uses and strategies in the city [5,7-9,11,24,47,70-78]; life-cycle and reuse of temporary structures [13,55-58,64,79-81]. Being conceived of as "temporary," pop-up environments are characterized by two fundamental properties-they have an expiration date that refers to their period of use, intermediate between the previous one that was interrupted and the next one that has not yet begun, and they have an interchangeable function, and therefore their use can be adaptive and can vary with respect to its original function [13,15-18,24]. Although temporariness clearly indicates short-term experimental development, temporary successful functions can also be incorporated into permanent plans [5]. Since a univocal definition for "pop-up environments" has not yet been defined, a new definition is proposed, taking into consideration the sources found in the literature. A pop-up environment can be defined as a physical structure or a space that emerges quickly, that is designed to be impermanent and constructed to adapt the space, and that is meant to fulfil the user's functional and aesthetics requirements [13-25].

More specifically, from an architectural point of view, a pop-up environment can be intended as a type of construction that due to characteristics such as light-weight technologies and fast and easy assembly-disassembly operations, occupies the ground only temporarily, and being adaptable to different uses and target groups thanks to its flexible structures [14,16-19,21-24]. Furthermore, pop-up environments, by virtue of their temporary nature, are usually designed according to the criteria of economy, construction reversibility, and environmental sustainability, allowing their re-use in other contexts or recycling of units and components, with advantages in terms of speed and economy that normally would not be achieved with a traditional permanent design [24,47].

Having defined the meaning of the term, it is important to clarify the general contexts in which temporary pop-up environments have been developed. Probably, the first examples of pop-up environments occurred in the so-called "pop-up retail" trend of opening short-term sales spaces that last for days or weeks before closing down, often to catch onto a fad or timely event [82]. Introduced in the 1990s in large urban cities such as London, Los Angeles, Tokyo, and New York City, pop-up retailers are temporary retail spaces that sell merchandise of any kind, from art and fashion to tech gadgets and food. Pop-up retails are opened temporarily to take advantage of a faddish trend or seasonal demand-holiday markets, Halloween stores, and limited engagement experiential retail are all common examples of pop-up shops [82]. Pop-up shops are also beneficial to retailers: in a down market, sellers can obtain lower rents and shorter leases if they are looking to generate sales but have a limited amount of inventory. They may appear under short-term leases in abandoned retail spaces, which also provides landlords some reprieve [83]. Pop-up retail began extending into other genres around 2009, when temporary restaurants started popping up in various locations. Newbury Street in Boston has recently become a centre for pop-up retail, hosting temporary storefronts for many local brands [84].

Recently, temporary pop-up environments have become topic of discussion among planners and architects, following their application in emergency contexts as a result of natural disasters, such as earthquakes, bushfires, and flooding. Often, during these events, large numbers of people are displaced from their homes, which have suffered such damage as to make them uninhabitable, and require temporary housing $[48,53]$. According to disaster literature, temporary housing is intended as a place that serves the function to shelter people during the period from the time the disaster occurs until they are resettled in a permanent place to live, allowing people to return to their normal activities [54]. The use of pop-environments was strictly connected to emergency situations, but recently, the interest in temporary uses has broadened its range of application. The financial crisis of 2008 has slowed down private investment and subsequently reduced funding of urban development projects, provoking a crisis of planning and shrinking urban services, which encourages the use of temporary pop-up housing that can be economically and rapidly implemented $[5,8,11]$. Moreover, this can also apply in the case of the emergence of new migratory currents due to wars and climate change and to 
the inability of developing countries to provide sufficient infrastructure to keep pace with their rapid population growth. However, the global need for temporary housing is expected to increase [47].

Finally, in recent years, more and more often, the realization of pop-up environments has also been used as a method of re-appropriation of spaces otherwise cut off from the urban context. There are various examples of pop-up structures built in vacant plots or empty buildings before a future permanent destination is identified, with advantages not only from an urbanistic point of view but also providing social, economic, and environmental benefits. Furthermore, pop-up environments are often used in contexts of densely populated urban areas, where there are various practical and legal limitations due to the rigidity of urban plans and the preservation of historical heritage. In this way, it is possible to avoid some bureaucratic procedures, resorting to temporary structures to create infrastructures that improve the quality of urban spaces. Within the latter context, the aim of this research is to evaluate pop-up environments as urban planning tools through the investigation of already realized case studies.

\section{Research Approach}

New methods and tools are needed for sustainable urban development strategies, and the present paper proposes the use of pop-up environments and temporary strategies, understood as something that is deliberately programmed not to be permanent and that tends to have a deconstruction or exit strategy in place, as one of the potential solutions [70]. How, then, should pop-up environments be realized, and what are the requirements that their design should be based on? How can pop-up environments positively contribute to the context in which they find themselves? What are the criteria necessary to define temporary strategies planned in principle to have a limited duration?

\subsection{Pop-Up Environments_Criteria and Requirements}

As previously mentioned, the scarcity of sources in the literature regarding the design and implementation criteria of the pop-up environment has imposed the use of an inductive approach. The review of the literature made it possible to assess the key common aspects for the realization of temporary environments. Based on the interpretation of this data, general criteria are proposed, and their elaboration allowed for the recommendation of a series of general requirements that can be applied in different contexts related to temporary pop-up environments from an architectural and planning point of view.

First of all, the criteria for the realization of a good traditional architecture have been considered, which can be summarized in the three principles defined by Vitruvius in his most famous work entitled Ten Books on Architecture [32,33]. Vitruvius proposed a conceptual way of seeing buildings according to a triad. Based on this triad, architecture must be equipped simultaneously with utilitas, namely utility, functionality, and therefore distribution organization; firmitas, that is strength, solidity, and resistance to stress and external agents; and venustas, that is beauty or aesthetic pleasantness. Although it is difficult to fix the meaning of these three terms, it can be assumed that Vitruvius meant a kind of unity brought to components that, by themselves, are highly different. An architectural construction must, at the same time, guarantee structural stability and provide a functional and productive use of spaces that are also pleasant and liveable. Without strength, architecture is dangerous and ephemeral; without functionality, architecture is simply a large-scale sculpture; and without beauty, as Le Corbusier also pointed out [85], a building is simply a construction. Quaroni goes beyond the pragmatism of Vitruvio's definition and proposes an interesting way of analyzing the subject [86]. People need to live, to work, to meditate, to have fun, to rest, to defend themselves, and to be treated and, therefore, need to have the necessary architectural structures to satisfy these various needs (in other words, utilitas). People expect these structures to be suitable for the specific needs required, especially with regard to solidity, durability, protection from atmospheric agents, and protection of privacy (in other words, firmitas). Utilitas and firmitas are made by architects who exploit the experiences of the past and the rules of the present. With wise and skillful operations of fusion, the architects will be able to combine utility 
with solidity in a single complete and defined element, introducing the aesthetic component as a link between the other components (in other words, venustas). Apparently, the knowledge of utilitas and firmitas is clear, since it is linked to rationality and daily life. The knowledge of venustas is instead linked to personal and cultural aspects of each architect, and therefore it is not so clear. Consequently, the three Vitruvian components cannot be placed on the same level, but on different ones: the last component prevails over the first two, being itself the main key for the assembly of the first two [86].

These themes can be translated into general requirements, valid both in the case of permanent and temporary architectures, such as structural stability, good space arrangement, adequate acoustic and thermal insulation, the respect of hygienic-sanitary requirements (such as the presence of enough natural lighting and ventilation), and also of adequate beauty to be accepted by users. Furthermore, it is possible to define requirements associated with pop-up environments, relating also to the framework considered in temporary strategies, such as natural disasters or the demand for temporary housing and infrastructure $[46,47,55,60,61]$. These requirements can be organized following the principles of life-cycle assessments into main categories related to the design, construction, operation, and after-life phases of the temporary building. The design requirements concern the complex of processes that reach the definition of specific dictates and guidelines for the construction of the building, such as modularity and flexibility of use. The construction requirements instead concern the set of operations aimed at placing the product in the environment where it will be used and therefore include transport, assembly, and adaptability to the context. Then, the operation requirements concern the complex of activities aimed at the good use of the building throughout its life, from its realization to its maintenance, and therefore also related to economic and environmental aspects. The after-life requirements include considerations related to the reuse of the object in other contexts and the recyclability of its elements for new life cycles.

In the design phase, modularity is the degree to which a system's components may be separated and recombined, often with the benefit of flexibility and variety in use. In architecture, modularity allows the possibility of having a series of different units starting from the same modules. Depending on the specific needs indicated and thanks to the use of prefabricated modules, it is possible to create units that can be aggregated in multiple ways, thus ensuring a high degree of flexibility to the modular system and the architectural solutions. The concepts of standardization and modular coordination, essential to minimize production costs and on-site construction time, allow for the creation of a temporary modular living system capable of responding to the functional-spatial needs of the different users. The constructive modularity is important not only from the point of view of the single unit but also considering the object as a whole. Modularity can also be understood as the possibility of aggregating multiple housing solutions within the same lot in order to obtain space for multiple users, thus minimizing the utilization of available space. This can be achieved, for example, by the realization of pop-up environments that have already been designed with the possibility of aggregating the individual units together in order to save useful space, either "horizontally" or "vertically," with the creation of units that can be joined by means of junctions or joints [21].

The possibility of expanding, reducing, or altering a basic element is undoubtedly the simplest and most suitable method to meet ever-changing needs, and this also leads to the definition of another equally important requirement-flexibility of use. Flexibility is the ability to produce environments that can evolve and adapt to changes in users' lives or the use they make of them over time. It basically allows the building to inhabit temporary uses or contexts in its already foreseen temporariness. A construction can be defined as flexible if, for example, it has a free plan without elements that forcibly identify spaces, as in the case of too many partition walls, or that has movable walls that guarantee different configurations of space, and, perhaps above all, if it has a structure that allows for possible future expansion [18], allowing users of temporary housing to "make their own" home and make it closer to their models and needs.

Temporary users are a heterogeneous group of different family units, including singles, single parents, non-traditional families, and extended families. This is further complexified first by economic 
status and religious customs and second by the possible presence of a disruption in the biography of the users, as in the case of natural disaster or emigration. A model of flexible habitability can respond to new social demands characterized by changes in family units, inaccessible property costs, and support for the enormous masses in movement. In this way, flexibility is characterized not only from an architectural point of view, such as the possibility of implementing spaces and changing their intended use, but also as a means of achieving the satisfaction of each user's needs and respect for their customs and habits. Regarding the installation phase, it can be safely said that important requirements are speed and simplicity of realization. Often, the fulfilment of these requirements is implemented through the use of prefabricated elements, which can be realized in a single unit or by the composition of different smaller elements that are then mounted together. Prefabrication is the construction process in which the elements of the building construction are made off-site with industrial machinery in several workstations or in a factory and then assembled with codified procedures. The use of prefabrication has considerable advantages to on-site construction from a technical, economic, and environmental point of view [87]. First of all, the standardization of components and modules, with lightweight and high-quality products manufactured in a factory, ensures fast transport and storage ease of assembly and quick installation of the entire system. The prefabricated components are designed for easy assembly together on site, often with dry procedures, such as welding, bolting, or with joined elements, and therefore without the use of wet binders such as concretes or mortars. In this way, the installation times are drastically reduced, since it is not necessary to wait for the binder to complete its stiffening process. This process is prolonged over time, growing asymptotically, and is different depending on the binder used; for example, for concrete, it is considered completed within 28 days since, after this period, more than $90 \%$ of the overall mechanical strength has developed [88]. It therefore appears evident that pop-up environments composed of prefabricated elements can be completed relatively quickly and with industrial assembling techniques that do not make their construction complicated in the most diverse contexts. Furthermore, prefabrication allows for solutions that are extremely customizable, thus also managing to meet the flexibility requirements. Digital fabrication and rapid prototyping allow us to create solid and three-dimensional objects starting from digital drawings, offering new and innovative solutions. This is the case of 3D printing, which, in the construction field, allows a drastic reduction in construction time and costs, involving even less labor, and the creation of very complex shapes and designs, impossible to achieve with traditional processes, simply by adding material layer by layer [89]. Three-dimensional printing is combined with energy efficiency, but also sensitivity to environmental impact, thanks to experimentation with poor materials, waste or recycled materials, and the propensity for bioclimatic design and the use of natural materials [90].

Regarding the operation phase, perhaps the most important requirement is the affordability. Pop-up environments often consist of cost-effective solutions when compared to their respective permanent counterparts. Users to whom pop-up environments are addressed are often characterized by a precarious or modest economic availability - people struck by disasters that have lost their homes, students, migrants, or low-income families that are unable to compete with the inaccessible real estate costs due to their current situation. The economic convenience indicates the availability of the system to guarantee a housing unit with minimum cost [91].

Other important requirements for temporary pop-up environments are reversibility and sustainability, which define their role once their functional life is exhausted. The reversibility of the temporary home, understood as the possibility of being easily dismantled, is the capacity of a constructive process to return to the starting point "without leaving traces." The reversibility of the construction system depends on the attitude, already conferred in the design phase, to retrace the steps of realization backward without requiring a high complexity of the disassembly operations. The system is characterized by stratified components, designed to obtain a separation of materials, using techniques such as dry assembly, a minimally invasive ground connection, and the use of eco-compatible materials [91]. 
Sustainability in the economic, environmental, and social fields is the process of change in which the exploitation of resources, the investment plan, the orientation of technological development, and institutional changes are all in harmony and enhance current and future potential in order to meet the needs and aspirations of users [92]. From an economic and social point of view, sustainability is obtained by an adequate life cycle management, especially as regards the possibilities for the end-of-life, and therefore referring to the concept of "cradle to cradle" described by William McDonough [93] - a specific kind of assessment where the end-of-life disposal step for the product is a recycling process. According to Johnson [54], there are five possibilities of end-of-life for temporary structure-(1) long-term use of the units, often considered problematic due to social dysfunctions and illegal occupancy, but often this is the case of a temporary environments becoming permanent; (2) dismantling units and storing them to reuse in other contexts, keeping in mind the costs of dismantling, transporting, storing, and reassembling; (3) selling the units, or parts of them, to recover some of the costs, although certainly less than a half of the initial investment; (4) demolishing the units to sell or to donate its parts, but due to their final condition, they often have little value; (5) reusing the units to use them immediately in a new location [53,54]. Furthermore, Arslan states that temporary units should be able to be reused or recycled after the end of usage. The reuse and recycle contribute to the reduction of energy consumption and related emissions of the construction sector, which is the largest rate of global pollution [17]. Finally, about environmental sustainability, pop-up environments should meet eco-efficiency requirements, following the instructions of European environmental directives [94]. These documents regulate new buildings, therefore both permanent and temporary ones, with the aim of having them use very little energy for their operation and following cutting-edge construction criteria, making them so-called "net-zero energy buildings" (NZEBs), a term used to define a unit with high energy performance thanks to their construction, typological, and system features aimed at energy saving and $\mathrm{CO}_{2}$ emission reduction [95]. These strategies use passive systems, involving the exploitation of resources provided by the environment in which they are inserted (solar radiation, prevailing winds, topography) through the correct design of the shape, orientation, and envelope and, only later, the use of plants that use renewable resources. Active systems are inserted later, only after having considerably reduced the energy necessary for the management of the building, when it is possible to make use of renewable energies [95]. A critical evaluation of the studies was subsequently carried out by developing a grid to identify the requirements that pop-up environments and temporary structures must have in order to satisfy the needs of users. The identification of the requirements took place through an inductive approach, that is based on the interpretation of the data found in the literature. With this method, it is not a matter of ascertaining the only meaning but of tracing the meaning relative to the context through the text. The proposed grid lists the requirements deemed important for the implementation of pop-up environments on the basis of the literature review: modularity, flexibility, speed and simplicity of installation, affordability, reversibility, and second-life management.

The requirements defined so far have been summarized in Table 1, also indicating their positive impact and relevance in urban planning.

Following the definition of the requirements of temporary pop-up environments, it is now possible to analyze some case studies that had a positive impact on the city and thus proving to be a winning strategy in urban planning. The case studies were organized according to the context in which they were used. Vacant land, empty and abandoned buildings, urban central areas, and, finally, situations in which temporary uses become permanent are distinguished. 
Table 1. Requirements of temporary pop-up environments and their relevance for urban planning.

\begin{tabular}{|c|c|c|}
\hline Requirement & Definition & Relevance \\
\hline $\begin{array}{l}\text { Modularity } \\
{[18,48,53,57]}\end{array}$ & $\begin{array}{l}\text { Degree to which system's } \\
\text { components may be separated } \\
\text { and recombined }\end{array}$ & $\begin{array}{l}\text { Minimizing costs } \\
\text { Minimizing production time } \\
\text { Minimizing consumption of space }\end{array}$ \\
\hline $\begin{array}{l}\text { Flexibility } \\
{[18,48,57]}\end{array}$ & $\begin{array}{l}\text { Ability to produce environments } \\
\text { that can evolve and change }\end{array}$ & $\begin{array}{l}\text { Rapid implementation } \\
\text { Respect for users' uses and customs } \\
\text { Easy change of intended useAdaptability } \\
\text { to everyone's needs }\end{array}$ \\
\hline $\begin{array}{c}\text { Speed } \\
{[21,47,59]}\end{array}$ & $\begin{array}{l}\text { Ability to transport and install } \\
\text { environments quickly }\end{array}$ & $\begin{array}{l}\text { Easy transportation on site } \\
\text { Reducing construction time } \\
\text { Adaptability to different contexts }\end{array}$ \\
\hline $\begin{array}{l}\text { Simplicity } \\
{[18,47,91]}\end{array}$ & $\begin{array}{l}\text { Ability to install environments } \\
\text { easily in different conditions }\end{array}$ & $\begin{array}{l}\text { Low structural complexity } \\
\text { Easy assemble of elements }\end{array}$ \\
\hline $\begin{array}{l}\text { Affordability } \\
{[21,47,57,80,91]}\end{array}$ & $\begin{array}{l}\text { Economic possibility of } \\
\text { exploiting a specific resource }\end{array}$ & $\begin{array}{l}\text { Guarantee of adequate housing } \\
\text { Minimizing cost of use } \\
\text { Minimizing manutention }\end{array}$ \\
\hline $\begin{array}{l}\text { Reversibility } \\
{[47,54,57]}\end{array}$ & $\begin{array}{l}\text { Ability to return to the starting } \\
\text { point without leaving traces }\end{array}$ & $\begin{array}{l}\text { Reducing environmental impact } \\
\text { Reducing complexity } \\
\text { in disassembly operations }\end{array}$ \\
\hline $\begin{array}{l}\text { Second-life } \\
\text { management } \\
{[47,53-55,58]}\end{array}$ & $\begin{array}{l}\text { Ability to have sustainable } \\
\text { solutions for the end-of-life }\end{array}$ & $\begin{array}{l}\text { High quality control for products } \\
\text { Reuse/recyclability for new life cycles } \\
\text { Reducing energy consumption and } \\
\text { related } \mathrm{CO}_{2} \text { emissions }\end{array}$ \\
\hline
\end{tabular}

\subsection{Definition and Selection of Case Studies}

The case study, in the context of this paper, corresponds to an architectural object or a defined environment, which is characterized by the following "pop-up" criteria: modularity of design, flexibility of use, speed of realization, constructive reversibility, affordability, and second-life management. All are defined in the habit of the temporary time context, as these examples were born with the assumption of having a limited life. A diverse range of pop-up environment examples have been considered-buildings, public spaces, social communities, green and open areas, museum, and cultural events-in the most diverse geographical and morphological contexts.

This section has been divided into paragraphs, depending on the type of context in which the pop-up environments have been inserted. The first paragraph shows some examples of pop-up environments made in vacant lands, untenanted areas of the city that, due to the most varied reasons, have completely lost their function. These areas usually have a negative impact on the environment around them and on the neighborhood that is not identified in that place. The second paragraph deals, through three examples, with the theme of reusing empty and abandoned buildings through the use of pop-up environments. These buildings can be used as a "shell" for the realization of temporary pop-up structures inside them, at least until a different permanent purpose is given. The third paragraph deals with the theme of pop-up environments in central areas, that are those urban areas in city centres where the urban layout is completely defined and where there are various economic, technical and legal limitations regarding the possibility of carrying out new urban interventions. The proposed examples show how pop-up environments can represent an alternative to planning in contexts of high housing density and construction.

The main criteria with which the case studies were chosen was, first of all, the impact that these examples had on the city and its users, therefore dealing with pop-up environments that were born as a response to specific needs of citizens (often also following neighborhood and local movements) and that have contributed to improving the environmental conditions of the context in which they were inserted. Furthermore, it was decided to choose examples of pop-up environments not linked 
to the theme of temporary housing, of which there are many examples in literature, and therefore responding to different uses, mainly public ones. In describing the case studies, international examples from Europe, America, Africa, and Asia were considered, with the aim of having an overview of realized examples and assessing how they contributed to a positive impact in society, but also based on information available in this regard.

Although the different contexts considered have very different characteristics, it was possible to notice how the use of pop-up environments for temporary use has substantially responded to general needs and interests. It was therefore decided to list in a comparison grid the general parameters of the case studies considered so as to simplify the analysis of the common characteristics and how they must differentiate in order to meet the different needs for which they were created.

The parameters considered for the comparison grid of the case studies are listed in Table 2.

Table 2. Parameters considered for case studies' analysis.

\begin{tabular}{ll}
\hline \multicolumn{1}{c}{ Parameter } & \multicolumn{1}{c}{ Definition } \\
\hline Location & Place where the PUE is located \\
Plot Original Function & Area in which the PUE is located \\
Temporary Use & Intended use of the PUE \\
Project Time Duration & Intended time of the PUE \\
Background Purpose & Planification of the PUE \\
Criteria for Realization & Objectives and aims of the PUE in its context \\
Design and Materials & Physical description of the PUE and its elements \\
User Groups & Type of user for which the PUE is intended \\
Neighborhood Characteristics & Spatial context in which the PUE is located \\
Neighborhood Density & Number of users expected to use the PUE \\
Lifecycle of the PUE & Considerations on reuse or recycling \\
Economic Aspects & Costs and economic benefits \\
\hline
\end{tabular}

\section{Results}

\subsection{Pop-Up Environments in Vacant Plots}

The term "vacant plot" is associated with vast areas within the urban landscape made available for obsolescence or change of destination of use that have completely lost their primary meaning, generating a condition of perceptive emptiness and a reduction in social communication [76]. Urban space is often conceived as a connective function, but the presence of untenanted spaces leads to the creation of non-places, or spaces without identity, relationships and history. Consequently, even the identification of the inhabitant with his own living space becomes increasingly difficult. The void must be rethought and perceived as a multifunctional public space, as a place of personal life in which to spend time and as an aggregative and growth space of collective social life. This is possible through the insertion of landscape elements, such as water and greenery, in the city and by architectures to create new forms of relationship and new ways of constructing the complex spaces of contemporaneity [76]. These untenanted areas often have a negative impact on their environment, attracting undesirable activities and create negative feelings with the neighbors. Moreover, the presence of apparently useless spaces is unacceptable, taking into account the demand for open and public spaces where people can meet, express themselves and participate in the life of the city [71].

In this context, the possibility of using pop-up environments can allow for the reconnection of these vacant areas with the city in a fast and affordable way. Vacant plots can be considered as "temporarily out of order," as they are in a sort of range in their functionality. This may essentially be due to two different reasons, but both of them allow the realization of temporary strategies: the future function must still be determined, or the realization of the future function has been postponed for several possible reasons, including planning processes, financial complications, or unexpected technical problems. In the first case, the temporal perspective of temporal usages is essentially indefinite, with 
a lot of freedom on the different possibilities of realization. In the second case, the temporal perspective is limited, and the possibilities are also more restricted, as there is probably a plan for the area, but this does not exclude the possibility that this plan can be adapted under the influence of temporary use [71].

Below, some relevant examples of temporary strategies in vacant areas are presented, focusing on their contribution to urban development and the appropriation by the citizens of otherwise unused areas.

The "Limite-Limite tower" (Figure 1) was a temporary project, begun in 1999 and ended in 2004, in the Schaerbeek district of Brussels. The objective of the project was to create a public space and a social community in an impoverished and very populated area of the city. Both local authorities and the community were involved in choosing the site for the tower in order to guarantee the success of the project. The site envisaged for the temporary building for meetings and exhibitions was located in the center of a run-down neighborhood, in a vacant lot between the train station and residential districts. The area was formally sold by the municipality and the project financed by an investment fund. The architectural structure was a nine-meter-high building, with an exterior covered with translucent corrugated plastic and a metal interior applied to a wooden structure. For five years, it was the site of concerts, exhibitions, debates, and architectural laboratories, thus allowing the community to regain possession of and benefit from an otherwise abandoned site. In 2004, the tower had to be replaced with a permanent structure: it was dismantled, and the material was shipped to Northern Ireland, where it was used to build a new pavilion in the Belfast botanical garden [71,96,97].

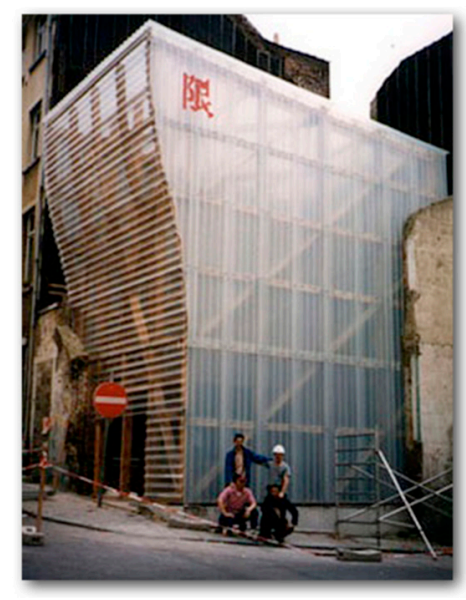

Figure 1. Limite-Limite Tower, Brussels, Belgium (C) City Mine(d)).

PROXY (Figure 2) is a temporary open space experiment, conceived and realized by Envelope A + D, that activates two empty urban areas in the heart of San Francisco's Hayes Valley district, which offers a more agile model for urban development and flexible urbanism. Conceived to have a temporary functional duration, PROXY is developed in two blocks of temporary buildings with the aim of creating a flexible environment of food, art, culture, and retailing in renewed containers. These blocks were made by repurposing disused containers for freight wagons. The containers used are the ISO model (acronym of International Organization for Standardization. With a width of eight feet $(244 \mathrm{~cm})$ and a height of eight feet and six inches $(259 \mathrm{~cm})$, they are common in two standard lengths of 20 and 40 feet $(610$ and $1220 \mathrm{~cm})$. The modularity of these modules has allowed for the creation of structures that can be quickly and easily assembled and dismantled with dry surfaces without the use of binders. Since 2011, PROXY has presented a rotation of events, retail stores, art and even food offers revolving through its open structure of temporary structures, invoking flexibility between people, architecture and cities. PROXY was born from neighborhood activism. In 2009, Hayes Valley was a difficult neighborhood for a long time on the verge of transformation; the removal of the central highway of the 1950s had put an end to an era of ruin and made the creation of new infrastructures that met the needs of the citizens necessary. When the recession threatened to block development for 
years, the community sought temporary uses to activate vacant sites. PROXY was originally granted a three-year lease on space in 2010 for $\$ 5000$ a month. A year later, the municipality modified this agreement to extend the lease to five years. The new agreement restores the PROXY lease agreement until January 2021, and the monthly rent on space increased to $\$ 7200$ in 2015, with a $2 \%$ increase each year thereafter. Today, PROXY, which hosts companies such as The Biergarten, Ritual Coffee, Smitten Ice Cream, and Streets of San Francisco Bike Tours, has become an innovative urban development model, as well as creating over 100 jobs and collaborating with community organizations to help local residents in developing small businesses [98].

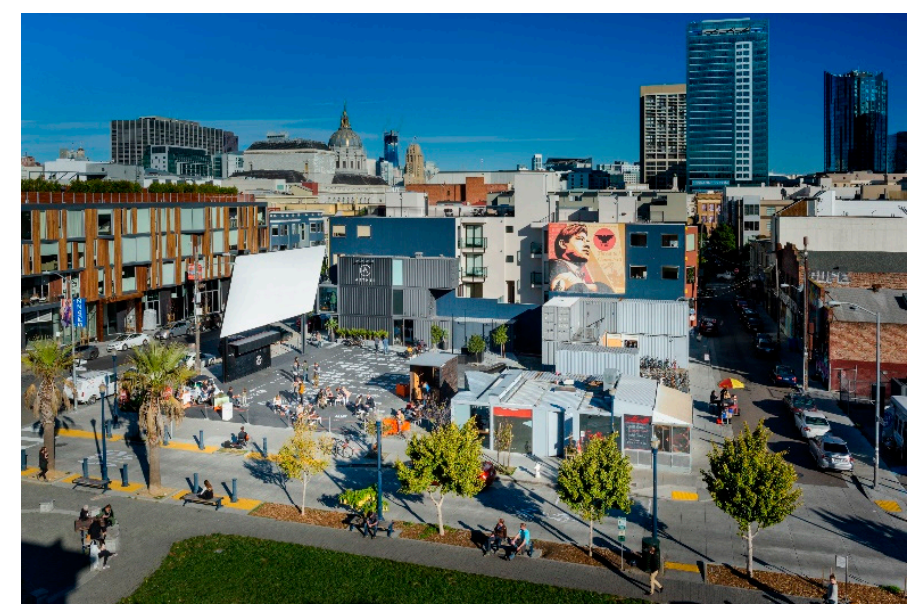

Figure 2. PROXY, San Francisco, USA (C Chris Woodcock for PROXY).

Another interesting example can be found in Berlin, in the district of Pankow, where in 1997, a process of urban modernization, which also included the improvement of green areas and public space has been started, with the project "Ein Platz für die Marie", promoted by AUN (Amt für Umwelt und Natur, the office for the environment) and various initiatives and associations of the district (Figure 3). The demolition of a district office left about $6000 \mathrm{~m}^{2}$ of uncultivated land, on which a police station, a fire station, and a playground for children of $1000 \mathrm{~m}^{2}$ had to be built. Due to the scarce finances of the local authorities that did not allow the construction of these buildings, the opportunity to temporarily use a building vacuum as a square and green area for residents of a central district of the city was presented. Thanks to the wide involvement of the residents in the whole process, who organized workshops on the temporary use of uncultivated land, in 1998, the 10-year free contract was signed with the possibility of extension between the municipality and the fire brigade (the owners of the area). The participatory planning of the area began, and, in order to reduce the high deficit of green spaces in the area, it was decided to allocate the area to an "urban square" with green areas and a children's playground. The square has been given a new look, with murals, mosaics, and a large fountain. New rows of trees and plants have been planted, and solar lighting systems have been installed. It was possible to achieve a high level of identification and a high quality of design at low costs (thanks also to about $€ 200,000$ of regional funds and monetary and in-kind donations to be added at the district's own quota) and at the same time, work promotion activities were carried out. 


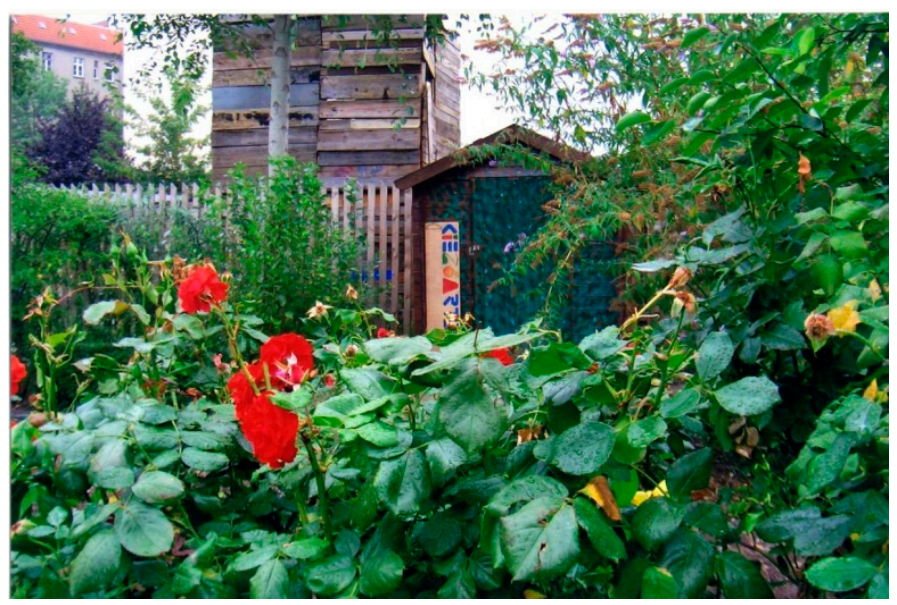

Figure 3. Green interim usage in Pankow, Berlin, Germany (C) S.T.E.R.N. GmbH).

A long-term improvement in the condition of open spaces has been achieved thanks to the intermediate phase of temporary use. The project, as well as the free-lease agreement, lasted about 10 years, and in 2006, the temporary experience ended, and the project was consolidated with the integration of a nursery and a gym [99]. The project was nominated by the "Gustav Meyer Award" in 1999 for exemplary planning methods and was awarded the "Social City" program in 2000 and the "City Belongs to Children" program in 2004.

A very interesting example, in a no-conventional "vacant plot," is the "Floating School" (Figure 4) in Makoko, a highly dense and urbanized settlement south of Lagos, built on stilts over water and known as the "Venice of Africa." Due to its characteristics, Makoko has yet no roads, no land, and no modern infrastructure. Until the realization of the Floating School, Makoko was served by only one primary school, built on uneven reclaimed land and susceptible to recurrent flooding, threatening local children's access to education. In response to this and in close collaboration with the Makoko community, the architect Adeyemi of NLÉ Architecture developed a prototype floating structure to serve as primary school. The project was initially self-funded by NLÉ, but a grant and a funding were later received to carry out comprehensive research on the community, being the project goals in line with the objectives of the climate change programme. Construction began in 2012, and it saw completion by the following year.

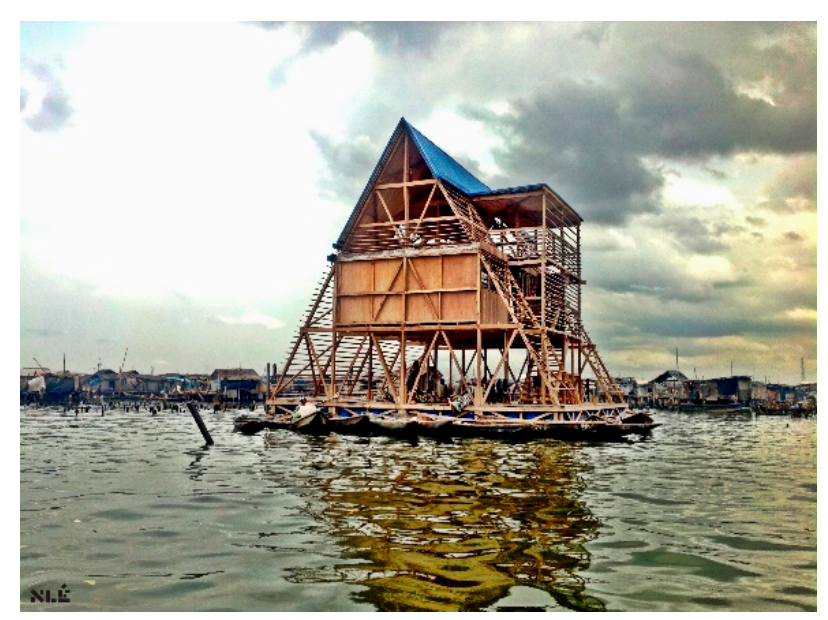

Figure 4. Floating School, Makoko, Lagos, Nigeria (C NLÉ).

The structure consisted of a 10-m-high pyramid, similar to a triangular A-frame, which is structured on a floating square base of $10 \mathrm{~m}$ side, supported by stilts. It was built from locally sourced 
wood, timber, and bamboo procured from a local sawmill and by recycled empty plastic barrels, found abundantly in Lagos, that were used for the buoyancy system, which consisted of 16 wooden modules, each containing 16 barrels. It clearly shows how available materials in the local neighbourhood have been utilized to get the best possible results. The barrels were also used to store excess rainwater, which is collected from the rainwater-collecting system. There were three levels-an open play area and community space; an enclosed space for classrooms up to 50 students, connected by stairs to the play area and surrounded by greenery; and a semi-enclosed workshop space. The classroom spaces were big enough to be used for communal functions, especially during out-of-school hours. The school was naturally aerated and ventilated so there was no need to find energy from an external source to ventilate the classrooms and provide a convenient space for kids to study. Sustainable features included application of solar cells to the roof, rainwater catchment systems and composting toilets. The structure cost $\$ 6250$ and was designed for a duration of five years, but the lack of maintenance has progressively weakened the structure, and the students were relocated due to safety concerns. The school collapsed in 2016 due to heavy rain, but the experiment was a promoter of educational and cultural programs in the coastal regions of Africa [100,101].

In Table 3, the examined case studies are listed in the comparative grid.

Table 3. Comparative grid for pop-up environments in vacant plots.

\begin{tabular}{|c|c|c|c|c|}
\hline Requirement & $\begin{array}{c}\text { Case Study } 1 \\
\text { Limite-Limite Tower }\end{array}$ & Case Study 2 PROXY & Case Study 3 Pankow & $\begin{array}{c}\text { Case Study } 4 \\
\text { Floating School }\end{array}$ \\
\hline Location & $\begin{array}{l}\text { Noord-Brabant, } \\
\text { Brussels, Belgium }\end{array}$ & $\begin{array}{l}\text { Hayes Valley, San } \\
\text { Francisco, USA }\end{array}$ & $\begin{array}{l}\text { Pankow, Berlin, } \\
\text { Germany }\end{array}$ & $\begin{array}{l}\text { Makoko, Lagos, } \\
\text { Nigeria }\end{array}$ \\
\hline $\begin{array}{l}\text { Plot Original } \\
\text { Function }\end{array}$ & Vacant plot & Vacant plot & Vacant plot & Vacant lagoon plot \\
\hline Temporary Use & $\begin{array}{c}\text { Social and cultural } \\
\text { events }\end{array}$ & $\begin{array}{c}\text { Social and cultural } \\
\text { events }\end{array}$ & Green area & School \\
\hline $\begin{array}{l}\text { Project Time } \\
\text { Duration }\end{array}$ & 5 years & 3 years (extended to 10 ) & 10 years & 5 years (lasted up to 3 ) \\
\hline $\begin{array}{l}\text { Background } \\
\text { Purpose }\end{array}$ & $\begin{array}{l}\text { Requested by } \\
\text { the community and } \\
\text { local authorities }\end{array}$ & $\begin{array}{l}\text { Born from neighborhood } \\
\text { activism }\end{array}$ & $\begin{array}{l}\text { Workshops promoted } \\
\text { by community }\end{array}$ & Educational program \\
\hline $\begin{array}{l}\text { Criteria for } \\
\text { Realization }\end{array}$ & $\begin{array}{l}\text { Creation of public } \\
\text { spaces } \\
\text { in impoverished areas }\end{array}$ & $\begin{array}{l}\text { Creation a flexible } \\
\text { environment of retailing }\end{array}$ & $\begin{array}{l}\text { Construction of urban } \\
\text { garden playground }\end{array}$ & $\begin{array}{l}\text { Construction of } \\
\text { floating building }\end{array}$ \\
\hline $\begin{array}{l}\text { Design and } \\
\text { Materials }\end{array}$ & $\begin{array}{l}\text { Wooden structure } \\
\text { covered in metal and } \\
\text { with translucent } \\
\text { corrugated plastic }\end{array}$ & ISO model containers & $\begin{array}{l}\text { Murals and mosaics, } \\
\text { new rows of trees, } \\
\text { solar lighting systems }\end{array}$ & $\begin{array}{c}\text { Wooden structure with } \\
\text { timber and bamboo. } \\
\text { Barrels buoyancy } \\
\text { system }\end{array}$ \\
\hline User Groups & Local community & $\begin{array}{l}\text { Local community, } \\
\text { companies, artists }\end{array}$ & Local community & Local students \\
\hline $\begin{array}{l}\text { Neighborhood } \\
\text { Characteristics }\end{array}$ & $\begin{array}{l}\text { Center of a rundown } \\
\text { neighborhood }\end{array}$ & $\begin{array}{c}\text { Absence of } \\
\text { infrastructures and } \\
\text { public spaces }\end{array}$ & $\begin{array}{l}\text { Area lacking green } \\
\text { areas and open spaces }\end{array}$ & $\begin{array}{l}\text { Area lacking primary } \\
\text { school }\end{array}$ \\
\hline $\begin{array}{l}\text { Neighborhood } \\
\text { density }\end{array}$ & Highly dense area & Highly dense area & Highly dense area & Highly dense area \\
\hline $\begin{array}{l}\text { Lifecycle of } \\
\text { the PUE }\end{array}$ & $\begin{array}{l}\text { Reuse of materials } \\
\text { in another context }\end{array}$ & $\begin{array}{l}\text { Reuse of containers for } \\
\text { new cycles }\end{array}$ & $\begin{array}{l}\text { Project consolidated } \\
\text { in permanent plans }\end{array}$ & $\begin{array}{c}\text { Use of local and waste } \\
\text { materials for } \\
\text { the design }\end{array}$ \\
\hline Economic Aspects & $\begin{array}{l}\text { Area sold by } \\
\text { municipality. Project } \\
\text { financed by fund }\end{array}$ & $\begin{array}{c}\text { Area formally let by } \\
\text { the municipality to } \\
\text { the companies at } \$ 7200 \\
\text { a month }\end{array}$ & $\begin{array}{l}\text { 10-years-free are use. } \\
€ 200,000 \text { of regional } \\
\text { funds }\end{array}$ & $\begin{array}{l}\text { Structure costed } \$ 6250 \text {. } \\
\text { Funds and grants } \\
\text { received }\end{array}$ \\
\hline
\end{tabular}

\subsection{Pop-Up Environments in Empty Buildings}

In the city, buildings often survive their original purpose and end up being degraded due to their obsolescence. Examples are factories, hotels, warehouses, and all the abandoned industrial sites that 
are part of the urban context of many cities. Such empty buildings can represent both a limit to city development and a potential for city building. In the last few decades, empty and abandoned industrial sites have become more and more interesting for urban planning, not only because of the phenomenon of the evaluation of industrial heritage but also because of the lack of available land [22]. The reuse of empty buildings has many advantages, being potentially cheaper and more environmentally friendly than the construction of new buildings, but also socially, with a positive impact on the quality of life in neighborhoods while preserving the memory of the past. The renovation of buildings also has a positive impact from the point of view of transport, energy conservation, and raw materials, since the structures are already there, so large quantities of new building materials are not required $[13,20]$.

However, the renovation of these buildings often entails huge costs, especially if they are already in an advanced state of degradation. Thus, empty buildings often remain in a state of neglect for a long time, contributing more and more to the deterioration of the area in which they are located. In this context, the use of pop-up environments, characterized by the principles of economic affordability, constructive modularity, and flexibility, in the indoor spaces of empty buildings would allow for the temporary use by the community without compromising any future permanent use. Furthermore, it would be possible to avoid heavy renovation work on empty buildings in favor of simple safety measures and routine maintenance.

Similarly, as with vacant plots, temporary uses can be a quick way to allow citizens to reclaim empty buildings by implementing projects that meet the demands of the contemporary city. The spaces can be used for temporary projects until a different permanent purpose is given. Some interesting examples of temporary interventions in empty or abandoned buildings are analyzed below.

In 1997 the municipality of Amsterdam announced a public competition of ideas to grant temporary use of the large abandoned industrial building of NDSM Wharf (Figure 5), with the aim of establishing a strong settlement core that could pave the way for a new development of the area. An association of local artists, architects and urban planners created a 10-year temporary reuse and management project. This vision became reality in 2003 when, thanks to public funding, a series of light architectural interventions transformed the entire complex into a center for artistic production and entertainment able to offer workspaces and events. The strategy put in place consisted of the use of prefabricated units for the creation of ateliers, places of work and testing, to be let at affordable prices for different periods and with the aim of transforming spaces so as to be self-managed, self-designed, and self-financed. Following the success of this temporary experiment, the project duration has been extended and is still to date active and an integral part of the city [102].

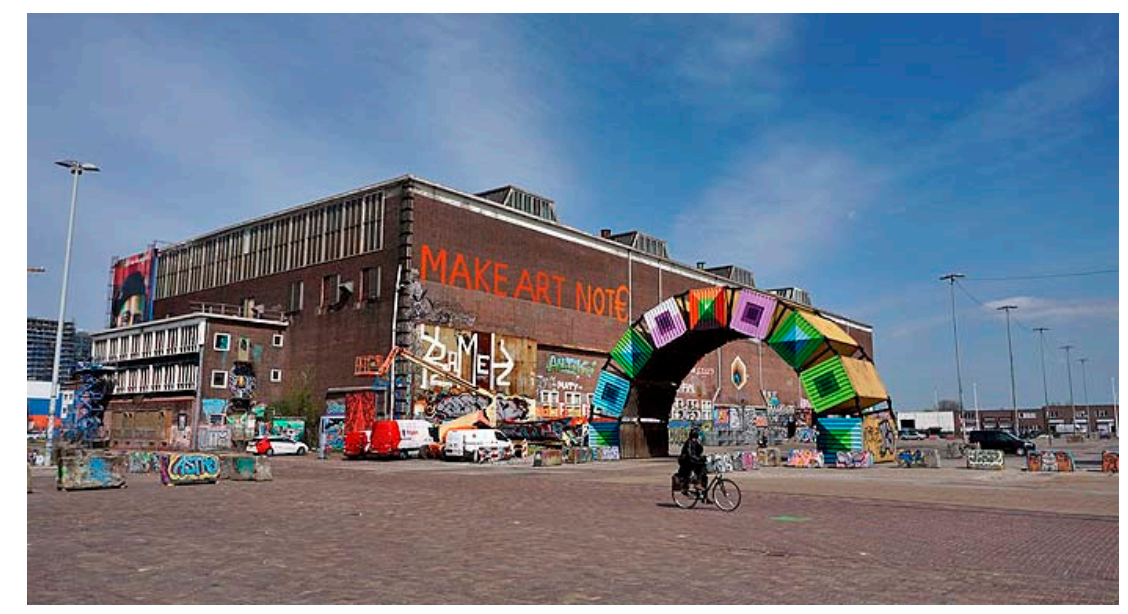

Figure 5. NDSM Wharf, Amsterdam, the Netherlands (C AmsterdamTips.com).

Other interesting examples can be found in Leipzig in the period immediately following the fall of the Berlin Wall. Sub-urbanization and migration due to high unemployment following the reunification 
of Germany and the socio-political change have led to a massive presence of residential buildings and empty offices in many formerly East-German cities. Leipzig has been particularly affected by this crisis-around one fifth of the population has left the city since the end of the 1990s, and almost 2000 buildings are empty and in danger of collapse. In 2004, on the basis of a neighborhood popular movement, the HausHalten association was founded with the aim of saving empty buildings at risk of disintegration through temporary interventions. The basic idea is to preserve homes by using them for the mutual benefit of owners and users, who become "custodians" as temporary users and get very large spaces at low fees, at the same time preventing the neglect of time and vandalism. The owners offer very convenient lease contracts and can consequently overcome the costs of use and maintenance. Activities that have a cultural or social impact on the neighborhood are given preference, and each contract has a duration of five years. The association acts as a mediator between the owners, users, and the city, contacting the owners of empty buildings, determining the necessary security measures, and helping to create temporary spaces that can be used for public interest purposes. Since these empty buildings were usually in poor condition, the use of prefabricated units in interior spaces was often considered to avoid heavy maintenance. To date, the association has reactivated over thirty properties, producing places of cultural enjoyment, art galleries and clubs, consequently reactivating entire regions (Figure 6). Near to these buildings, commercial activities have restarted, and neighborhoods have come to life again. The long-term objectives are therefore aimed at revitalizing entire parts of the city simply by setting up temporary interventions that ensure routine maintenance [103].

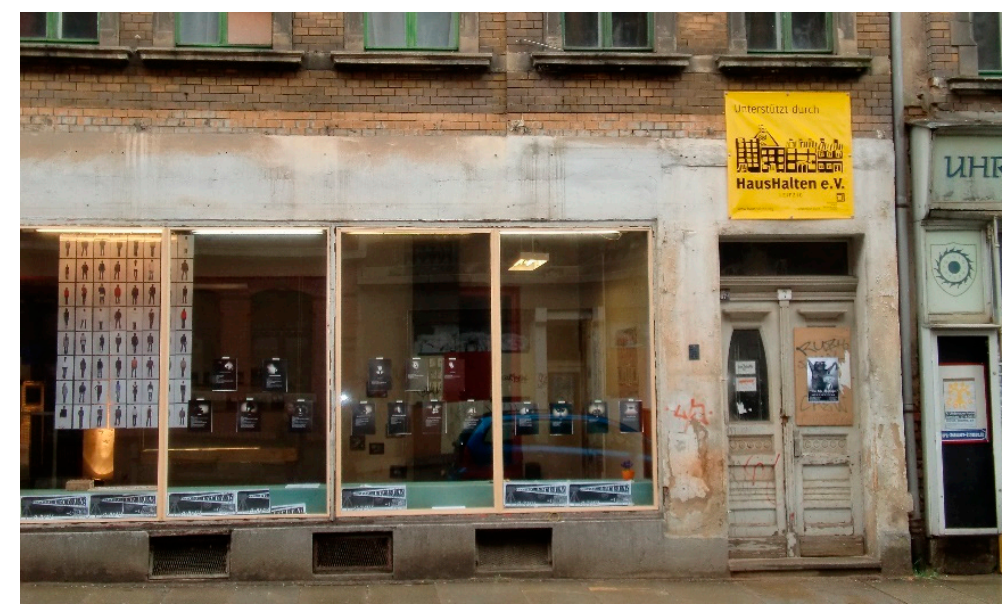

Figure 6. Abandoned building, Leipzig, Germany (C) HausHalten e.V.).

One of the most important temporary intervention projects on the empty buildings in Northern Italy is the "MADE in MAGE" (Figure 7) based in Sesto San Giovanni, near Milan. This is the re-use of a former industrial warehouse of approximately $1500 \mathrm{~m}^{2}$, recently renovated to house a selection of companies from the Italian creative industries, primarily those that practice craftsmanship in various forms. In 2011, an agreement between the municipal administration and the project coordinator allowed them to obtain a first three-year contract with a low rent, essential to give the opportunity to invest time in exchanges and mutual collaborations. During the project, a creative community was born, made of a dozen companies and entrepreneurs from the artisan sector and sustainable design. Tenants were invited to choose between different types of pop-up units built within the former factory, ranging in size from 25 to $100 \mathrm{~m}^{2}$, to be able to realize their own private atelier, also taking care of the furnishing of common areas. This temporary project was financed entirely with regional funds, and temporary tenants had to bear only the costs for utilities. These collective projects, implemented through temporary interventions to improve the space, spread to the surrounding city, inviting creative companies to participate in the main local events of the community [104]. 


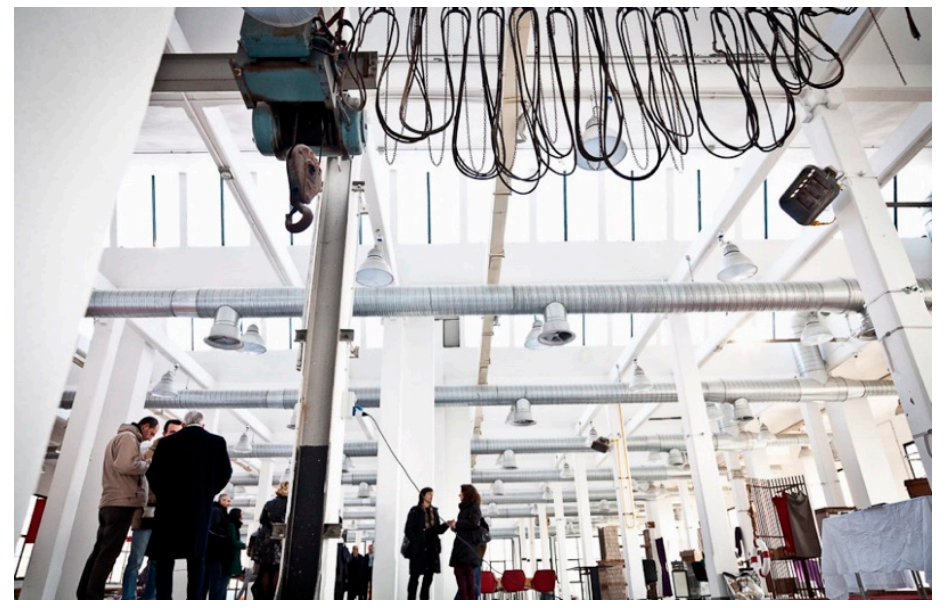

Figure 7. MADE in MAGE, Sesto San Giovanni, Italy (C) Elia Rollier for temporiuso).

In Table 4, the examined case studies are listed in the comparative grid.

Table 4. Comparative grid for pop-up environments in empty buildings.

\begin{tabular}{|c|c|c|c|}
\hline Requirement & Case Study 5 NDSM & Case Study 6 Leipzig & $\begin{array}{l}\text { Case Study } 7 \text { MADE } \\
\text { in MAGE }\end{array}$ \\
\hline Location & $\begin{array}{l}\text { Port area, Amsterdam, } \\
\text { the Netherlands }\end{array}$ & Leipzig, Germany & Sesto San Giovanni, Italy \\
\hline Plot Original Function & Empty building & Empty buildings & Empty building \\
\hline Temporary Use & $\begin{array}{l}\text { Multipurpose cultural } \\
\text { meeting point }\end{array}$ & $\begin{array}{l}\text { Cultural events, } \\
\text { galleries, homes }\end{array}$ & Creative community \\
\hline Project Time Duration & 10 years with extensions & 5 years & 3 years \\
\hline Background Purpose & Public competition of ideas & $\begin{array}{c}\text { Neighborhood } \\
\text { popular movement }\end{array}$ & $\begin{array}{l}\text { Creative community of } \\
\text { companies met in association }\end{array}$ \\
\hline Criteria for Realization & $\begin{array}{c}\text { Establish a strong settlement } \\
\text { core for a new development } \\
\text { of the area }\end{array}$ & $\begin{array}{l}\text { Preserving empty buildings } \\
\text { and preventing the neglect } \\
\text { of time and vandalism }\end{array}$ & $\begin{array}{l}\text { Supporting crafts and } \\
\text { local businesses }\end{array}$ \\
\hline Design and Materials & $\begin{array}{l}\text { Prefabricated } \\
\text { light-weight units, } \\
\text { to be implemented } \\
\text { on the users' needs }\end{array}$ & $\begin{array}{c}\text { Prefabricated light-weight } \\
\text { units }\end{array}$ & $\begin{array}{c}\text { Prefabricated } \\
\text { light-weight units, to be } \\
\text { implemented } \\
\text { on the users' needs }\end{array}$ \\
\hline User Groups & $\begin{array}{l}\text { Workers, artisans, } \\
\text { small businesses }\end{array}$ & Low-income people & Industries \\
\hline $\begin{array}{l}\text { Neighborhood } \\
\text { Characteristics }\end{array}$ & Port area to be redeveloped & $\begin{array}{l}\text { Area subject to } \\
\text { sub-urbanization } \\
\text { and migration }\end{array}$ & $\begin{array}{c}\text { Residential area } \\
\text { characterized by lack } \\
\text { of infrastructure }\end{array}$ \\
\hline Neighborhood Density & Highly dense area & Poorly dense area & Highly dense area \\
\hline Lifecycle of the PUE & Reuse of prefabricated units & $\begin{array}{l}\text { Use of space otherwise } \\
\text { disbanded }\end{array}$ & $\begin{array}{c}\text { Use of space } \\
\text { otherwise disbanded }\end{array}$ \\
\hline Economic Aspects & $\begin{array}{l}\text { Rent of workplaces at } \\
\text { affordable prices for } \\
\text { fixed periods }\end{array}$ & $\begin{array}{c}\text { Mutual economic benefit of } \\
\text { owners and users }\end{array}$ & $\begin{array}{l}\text { Financed with regional } \\
\text { funds. The only costs are for } \\
\text { the utilities }\end{array}$ \\
\hline
\end{tabular}

\subsection{Pop-Up Environments in Urban Central Areas}

In city centers where the location and function of infrastructures and buildings are often well defined, there are several practical and legal limitations, such as the issue of preserving historical heritage and the rigidity of urban plans. It therefore becomes increasingly difficult to have concrete investment opportunities in these places, both public and private. In this context, pop-up environments 
can provide an opportunity for the construction of new infrastructures, so as to generate interest among citizens through short-term intensification or multiplication of use [8].

Temporary uses of pop-up environments allow for quick and flexible structures that are more easily accepted than permanent new structures, avoiding some bureaucratic planning procedures [5]. In the context of high density areas, characterized by high real estate costs and little investment opportunities, temporary uses can provide viable alternatives that enhance the quality of urban spaces and allow business opportunities and a rapid return on invested capital [8,11].

An interesting example of temporary intervention of this type was in 2005 in Vienna, with the "Add-On 20 Höhenmeter" project (Figure 8).

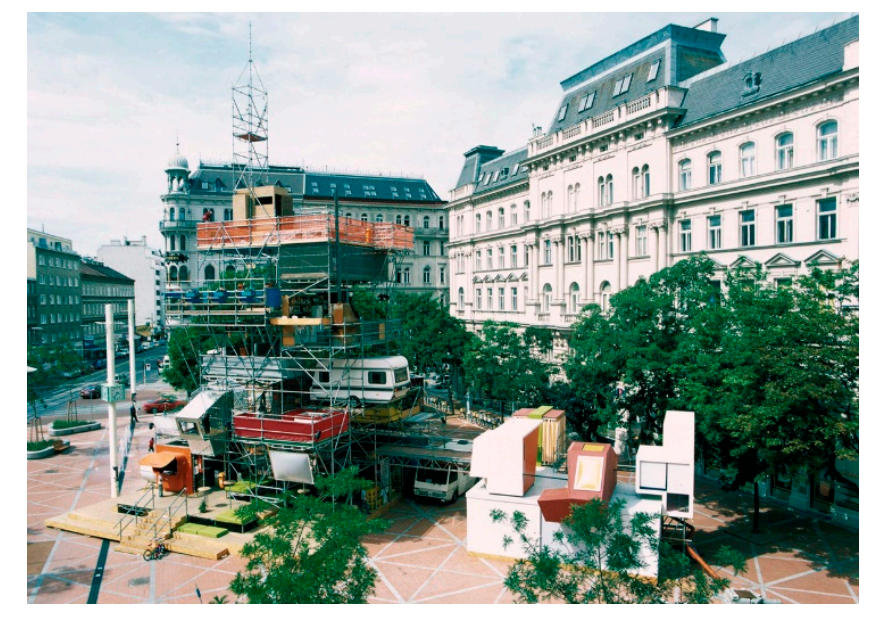

Figure 8. Add-On 20 Höhenmeter, Vienna, Austria (@) Michael Strasser for Fattinger-Orso).

"Add-On 20 Höhenmeter" is a huge architectural installation that, for six weeks, turned Wallensteinplatz into a center of artistic interaction. The basic structure consisted of a 20-m-high platform in which the specially designed space modules fitted together creatively using low-cost light prefabricated structures based on a scaffolding model. As a freely accessible environment, this structure allowed visitors to explore new landscapes, offering a range of angles and views at various levels, and the result was a fascinating variety of perspectives on everyday life. Every day, there was a program of different artists with cultural and multidisciplinary shows. As a vertical public space, it explored the interface between public and private spheres through the implementation in the public space of recognizable functional units of everyday life, but out of context, trying to show a reaction to the stereotyped forms of functionality of social life, motivating the passers-by to explore urban life in a more interactive way. At the end of the temporary use, the tower was dismantled, and a large part of its components were recycled $[73,105]$.

Another interesting example of temporary artistic intervention took place in New York in 2005. The intervention, named "The Gates" (Figure 9), was created by the artists Christo and Jeanne-Claude, who installed 7503 vinyl "gates" along $37 \mathrm{~km}$ of paths in Central Park. In each gate hung a saffron-colored nylon fabric panel. The exhibition took place with the aim of provoking new looks and new spatial sensations in the well-known public space of New York. The artists used the premise of the ephemeral combined with the plasticity and originality that give the work the desired urban relevance. The total materials used were 5390 tons of steel, $96 \mathrm{~km}$ of vinyl tubing, $99,155 \mathrm{~m}^{2}$ of fabric, and 15,000 sets of brackets and hardware. 


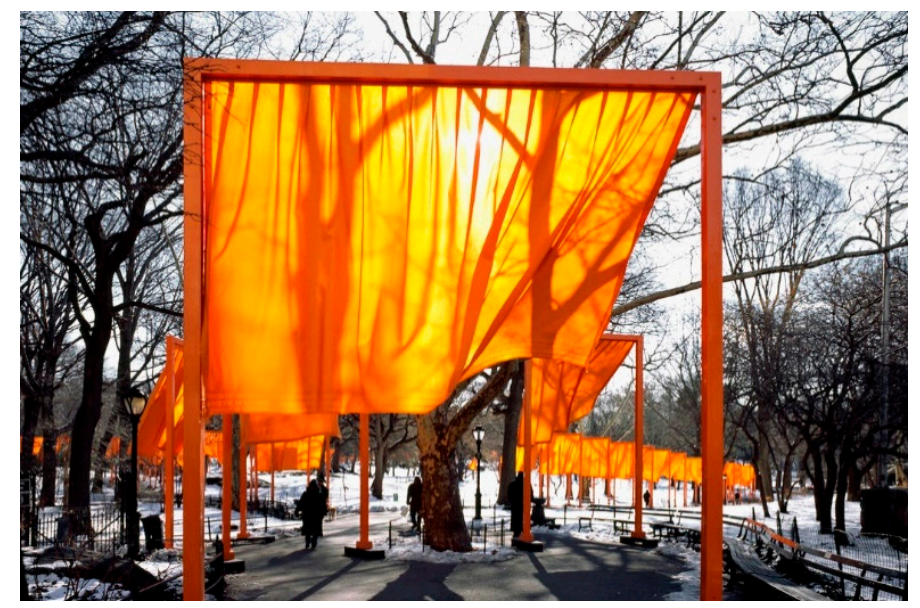

Figure 9. Central Park Gates, New York, USA (C) Christo and Jeanne Claude).

The gates were assembled in a Long Island facility, then trucked to Central Park, while the textile was produced and sewn in Germany. As one of the conditions for the use of the park space, the steel bases were based on walkways, but they were not attached, so that no holes and no permanent changes to the park were made. The gates were appreciated for illuminating the desolate winter landscape and encouraging late-night pedestrian traffic in Central Park. Seen from the buildings surrounding Central Park, the gates looked like a golden river that appeared and disappeared through the bare branches of the trees and highlighted the shape of the winding paths. The artwork, which was fully funded by its creators, remained for 16 days; thereafter, the gates were removed, and the materials were recycled $[73,106]$.

The "Floating Pavilion" (Figure 10) was a temporary pop-up environment exhibited in Taiwan that lasted for three months in 2016. Designed by the architect Shen Ting Tseng, it was erected in the square in front of the Taipei Fine Art Museum. The square is located on the edge of the urban area and adjacent to the riverbank, and due to the unbearable strong wind and the subtropical sunlight, museum visitors usually hurry inside the building, leaving the square a place lacking vitality. Based on the concepts of wind and light, the Floating Pavilion directly responds to the site's conditions. The structure presented two levels covering an area of approximately $250 \mathrm{~m}^{2}$ : a kite canopy and a plastic curved island platform are joined by slim steel poles and interlinked from above and below in order to create a pavilion that floated on the square, capturing the breeze and light. The kite canopy consisted of 320 box-shaped kites that swayed gently, encouraging a sense of relaxation for the place, and acted as an interface that transformed the sunlight, depicting diverse faces of light and shade across different time of the day. Below the kite-canopy, the curved island platform ascended toward the centre of the pavilion, where guests were encouraged to lay under the shades or sliding down from the curved slopes. At the very center, a pink spherical void within the island allowed guests to climb inside the pavilion, where a secluded area was revealed, offering a completely different spatial experience. Through the interaction between kite canopy and natural forces, a new way of perceiving the space was provided, and the scheme sought to activate the square, transforming it into a vibrant public area. Furthermore, a new way of perceiving the environments was suggested by revealing the interactions between the kites and nature; moreover, the square became a place where visitors were attracted and engaged, providing both intimacy and publicity at the same time. After the summer, the Pavilion was disassembled and stored, with the possibility of being reused for particularly hot summers $[107,108]$. 


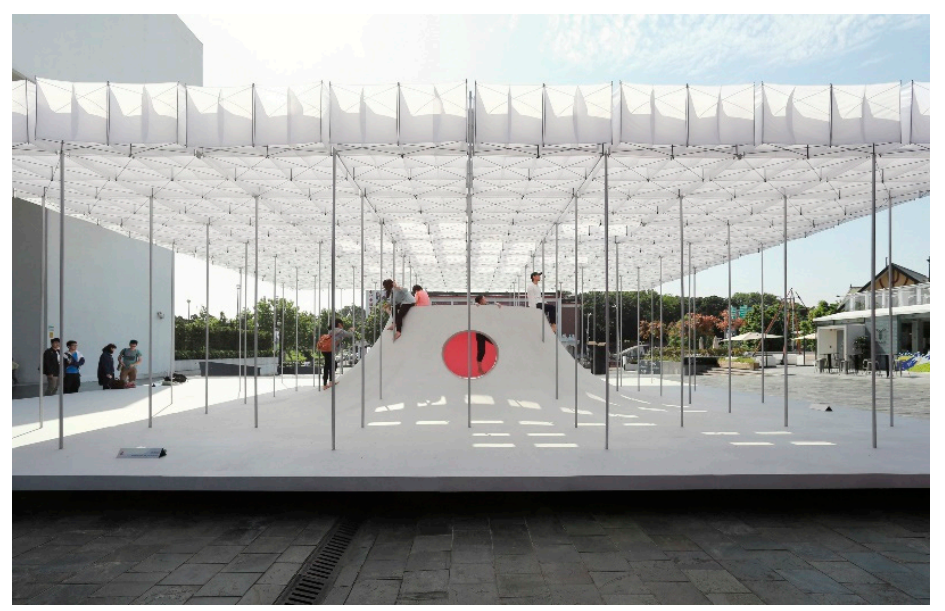

Figure 10. Floating Pavilion, Taiwan, Japan (C) shentingtseng architects).

Finally, it is worth mentioning an interesting example of a temporary pop-up environment aimed at integrating historic buildings in the urban context, created in Paris in 2008. The "Fondation Suisse" is the most important dormitory in the city, and on the occasion of its 75th anniversary, the city commissioned the realization of the "Hovercraft" (Figure 11. This was a temporary solution for a recurring problem: the missing space for large parties. In summer, the open spaces at the base of the building are perfect, but in November, it was too cold, so it was decided to "wrap" the space under the building with an inflatable and translucent membrane. The present pneumatic room transformed the semi-public environment into a semi-private event space, and for three days, the pneumatic room held concerts, ceremonies, conferences, and parties. In this way, thanks to a fast and low-cost solution, it was possible to avoid alternative solutions that would have involved a greater funds $[14,109]$.

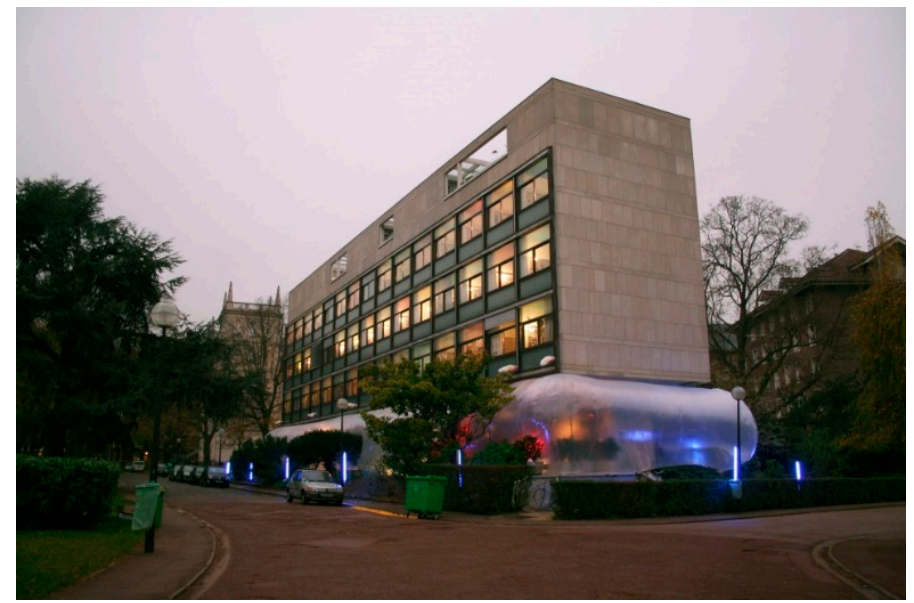

Figure 11. Hovercraft, Paris, France (C) raumlaborberlin).

In Table 5, the examined case studies are listed in the comparative grid. 
Table 5. Comparative grid for pop-up environments in urban central areas.

\begin{tabular}{|c|c|c|c|c|}
\hline Requirement & Case Study 8 Add-On & $\begin{array}{l}\text { Case Study } 9 \\
\text { The Gates }\end{array}$ & $\begin{array}{c}\text { Case Study } 10 \\
\text { Floating Pavilion }\end{array}$ & $\begin{array}{c}\text { Case Study } 11 \\
\text { Hovercraft }\end{array}$ \\
\hline Location & Vienna, Austria & New York, NY, USA & Taiwan, Japan & Paris, France \\
\hline $\begin{array}{l}\text { Plot Original } \\
\text { Function }\end{array}$ & Urban central area & Urban park & Urban square & Historical building \\
\hline Temporary Use & Public space & Art exhibition & Pavilion & $\begin{array}{l}\text { Appropriation of } \\
\text { open spaces }\end{array}$ \\
\hline $\begin{array}{l}\text { Project Time } \\
\text { Duration }\end{array}$ & 6 weeks & 3 weeks & 3 months & 3 days, every year \\
\hline $\begin{array}{l}\text { Background } \\
\text { Purpose }\end{array}$ & $\begin{array}{l}\text { Creating a vertical } \\
\text { public space }\end{array}$ & $\begin{array}{l}\text { Illuminating } \\
\text { the landscape and } \\
\text { encouraging } \\
\text { night traffic }\end{array}$ & $\begin{array}{l}\text { Reactivation of square } \\
\text { lacking vitality }\end{array}$ & $\begin{array}{l}\text { Search for a practical } \\
\text { solution for } \\
\text { missing space }\end{array}$ \\
\hline $\begin{array}{l}\text { Criteria for } \\
\text { Realization }\end{array}$ & $\begin{array}{l}\text { Exploration of new } \\
\text { landscapes }\end{array}$ & $\begin{array}{l}\text { Provoking new looks } \\
\text { and new spatial } \\
\text { sensations }\end{array}$ & $\begin{array}{l}\text { Protection from wind } \\
\text { and tropical sun }\end{array}$ & $\begin{array}{l}\text { Appropriating } \\
\text { temporary outdoor } \\
\text { spaces }\end{array}$ \\
\hline $\begin{array}{l}\text { Design and } \\
\text { Materials }\end{array}$ & $\begin{array}{l}\text { Scaffolding model with } \\
\text { light prefabricated } \\
\text { structures }\end{array}$ & $\begin{array}{l}\text { Vinyl gates with } \\
\text { a saffron-colored nylon } \\
\text { fabric panel }\end{array}$ & $\begin{array}{c}\text { Kite canopy and plastic } \\
\text { platform joined by slim } \\
\text { steel poles }\end{array}$ & $\begin{array}{l}\text { Inflatable and } \\
\text { translucent membrane }\end{array}$ \\
\hline User Groups & Local community & Local community & $\begin{array}{l}\text { Local community and } \\
\text { visitors }\end{array}$ & Students \\
\hline $\begin{array}{l}\text { Neighborhood } \\
\text { Characteristics }\end{array}$ & $\begin{array}{c}\text { Densely built central } \\
\text { urban area }\end{array}$ & $\begin{array}{c}\text { Densely built central } \\
\text { urban area }\end{array}$ & $\begin{array}{l}\text { Densely built central } \\
\text { urban area }\end{array}$ & $\begin{array}{l}\text { Densely built central } \\
\text { urban area }\end{array}$ \\
\hline $\begin{array}{l}\text { Neighborhood } \\
\text { Density }\end{array}$ & Highly dense area & Highly dense area & Highly dense area & Highly dense area \\
\hline $\begin{array}{l}\text { Lifecycle of } \\
\text { the PUE }\end{array}$ & $\begin{array}{l}\text { Dismounted and } \\
\text { recycled }\end{array}$ & $\begin{array}{l}\text { All the materials were } \\
\text { recycled }\end{array}$ & $\begin{array}{l}\text { Dismounted, stored } \\
\text { and reused }\end{array}$ & $\begin{array}{l}\text { Dismounted and } \\
\text { reused }\end{array}$ \\
\hline Economic Aspects & Low cost installation & $\begin{array}{l}\text { Fully funded by } \\
\text { the creators }\end{array}$ & Low cost installation & Low cost installation \\
\hline
\end{tabular}

\section{Discussion}

This study shows how the use of temporary pop-up environments can represent a solution to some of the problems that characterize modern urban planning. Temporary uses allow the city to evolve quickly without the risk of slowing down urban planning when compared with the rapid change of uses and customs and the speed of technological innovation $[5,24,47]$.

Given the lack of unambiguous definitions in the literature regarding the construction criteria and the requirements of pop-up environments [24], this paper has proposed to fill these gaps through an interpretative approach. A series of general requirements has been proposed that the pop-up environments must have in order to respond to the most diverse needs, thus also indicating how they can have a positive and relevant impact in urban planning. Modularity [18,48,53,57], flexibility [18,48,57], speed $[21,47,59]$ and simplicity of installation [18,47,91], economic affordability $[21,47,57,80,91]$, constructive reversibility $[47,54,57]$, and second-life management $[47,53-55,58]$ all derive mainly from the criteria for the design of temporary houses in case of natural disasters $[5,8,11,48,53,54]$ but are also applicable for other types of pop-up environments. It has been seen how the use of pop-up environments has had a positive impact in the most diverse contexts that often represented a limit or a problem for urban planning due to their intrinsic nature.

The presence of vacant plots in urban areas leads to the formation of spaces without identity and in which the citizens cannot identify themselves. However, the use of pop-up environments can allow the reconnection of these areas to the urban context thanks to the new temporary purpose [71,76]. It has also been understood how the use of temporary structures has often considered community involvement with the result of responding to their needs faster and cheaper than using permanent structures [96,97], creating the basis for productive urban models that lead to the creation of new jobs [98], allowing the realization of artistic and cultural events that can attract not only locals but also 
tourists [98], and allowing the creation of open and green public spaces in areas of the city where they are lacking and in which the community can express themselves [96,97,99,101].

The creation of pop-up environments in empty buildings has allowed for the reuse of structures that otherwise would have represented a limit to the development of the city. The use of these buildings to host pop-up environments has brought about considerable advantages, both from a technical point of view, as they are much cheaper and environmentally friendly than the construction of new permanent buildings, as well as from a social and historical point of view, as they improve the quality of the neighborhood without altering the historical memory of the past $[13,20,22]$. Another insight that has been gained through this analysis is how pop-up environments inside empty buildings have allowed citizens to appropriate these unused spaces for the creation of spaces for productivity and work, as well as for artistic and cultural events [102-104].

Furthermore, pop-up environments can allow the creation of new infrastructures in the contexts of city centers, characterized by the desire to preserve the historical heritage, by the rigidity of urban plans, and by many practical, technical, and legal limitations $[8,11]$. In the context of these areas, pop-up environments are proposed as a valid alternative to traditional architectural planning, as these structures, which are quick to install, flexible, and reversible, allow users to meet their needs without affecting the historical heritage and evading any bureaucratic problems [14,73]. It has been seen, from the case studies, how pop-up environments have created new public spaces, otherwise impossible in the historic city center, defining not only new functions, such as cultural and artistic events, but also new perspectives panoramic and landscape for the city $[105,106,108,109]$.

The case studies presented have shown how desirable it is to implement the practice of temporary interventions in the cities. They show that where temporary experiences have been conducted with foresight, the effects produced on the urban environment have been concretely positive on several levels. The creation of social value, the production of cultural and lively environments, the care of real estate, the interception and redistribution of economic flows are all achievable objectives and, in many cases, achieved. It also appears that temporary uses act as social innovations characterized by new types of spaces, uses and organizations, presenting themselves as new political and economic models to contribute to urban transformation.

On the other hand, there is one very important aspect that needs to be considered: the possibility that a temporary pop-up environment become permanent, even if it was initially scheduled to have a time limit. In some cases, if a temporary use becomes permanent, it is because this has become particularly popular and is perceived as an essential element of the context in which it is found [11]. A very famous example is the Eiffel Tower in Paris, France, which was built for the 1889 Universal Exposition, should have remained in place no more than 20 years, but the infatuation of the Parisian people for the monument was so strong that it has been retained to this day [5]. In other cases, however, this phenomenon acquires a strongly negative value, especially in the social sphere, like in the case of temporary housing erected following natural disasters such as floods and earthquakes. In these cases, pop-up environments, conceived without the requirements of durability and long-term comfort, end up being a source of discontent among its users, who sometimes abandon or completely modify these "no longer temporary" houses [48]. Following the earthquake in Chile in 2010, for example, temporary post-emergency houses have been strongly criticized by the community, as they are considered inadequate for the climate of those areas. Because of their shelter necessity, people did not abandon these homes even when their temporal function was exhausted, but instead, they started to modify them to meet their needs. Among the most frequent modifications are extension of the house, insertion of thermal insulation, change of doors and windows, insertion of new openings, and insertion of internal partitions to divide the interior spaces. These changes were undertaken in order to obtain new spaces, to cope with the local climate and to facilitate local traditions [23].

It is therefore important that the strategies relating to temporary pop-up environments take into consideration the possibility that use becomes permanent so as to avoid harmful consequences for the urban area and planning temporary interventions from the beginning considering their potential 
longer duration. In this context, "incremental" strategies can be adopted that incorporate both the temporary nature concept of the pop-up environment and the possible permanence character within a complementary process that acts as a bridge between the two phases. Beneficial aspects are embodying economic, social, and environmental sustainability; saving enormous resources and materials; incorporating adaptable design; and providing cost-effective solutions that contribute to sustainable development. All of these elements pave the way toward a circular future in the affected countries. An example of this tactic was in Quinta Monroy, where the temporary housing units designed by architect Aravena were built on two floors with a space between the houses left empty to stimulate future expansion (Figure 12). Each "half-house" constituted a nucleus of a house that had to be completed by the residents and contained all the basic and essential elements and utilities that cannot be built by the residents, such as the supporting structure, stairs, bathrooms, and kitchens. The rest of the elements, such as partitions, interior fittings, and the remaining enclosure, would be left to be built by the residents. The final project provided a support framework that avoids the negative effects of self-construction on the urban environment over time and facilitates the expansion process that naturally arises in poor housing construction, for the entire period of temporary residence, and also in the event of a possible longer duration [57].

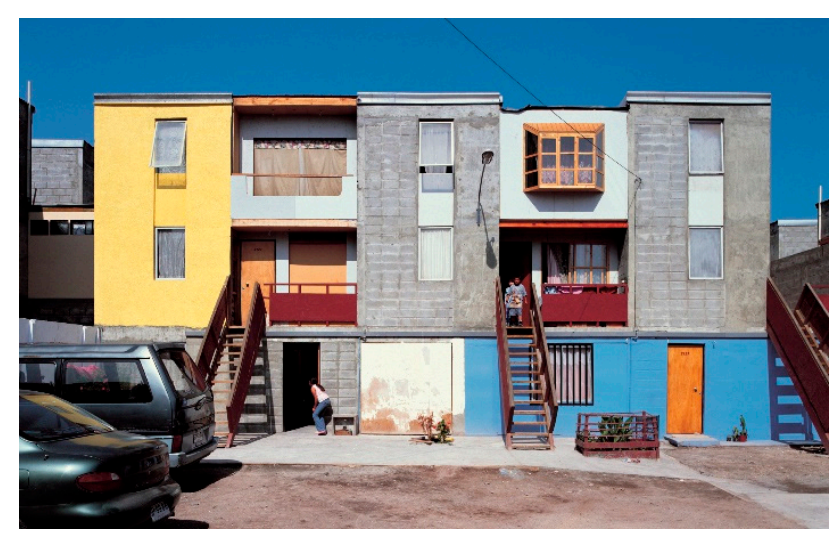

Figure 12. Quinta Monroy, Chile (C) Cristóbal Palma/Estudio Palma).

\section{Conclusions}

The temporary nature of pop-up environments is characterized by the changeability of the functions and destinations of use, integrated into the existing and permanent urban fabric, while maintaining recognition and local identity. The pop-up environment allows users to overcome the immutability of permanence and to be characterized as a solution to specific temporary needs of function and use, susceptible to continuous modification and adaptability. In this way, they do not produce a fracture within the permanent environment but integrate it and complete it by defining updated uses and functions and leaving the task of maintaining memory and identity to the historical architecture.

The use of pop-up environments is supposed to increase sustainability, incorporating the material life-cycle that can transform contemporary architecture, thanks to numerous construction advantages, summarized as lower costs, because the cost for prefabricated materials and their assembling on site are usually much lower than traditional construction methods; environmental friendly construction processes and the use of raw materials with low embodied energy (including recycled materials, construction and industrial waste); wet construction processes are minimized, so that building erection process generate less material wastes and dust compared to traditional methods, as well as allowing easier assembly and disassembly operations that, in many cases, allow for the complete reversibility of the project; and time savings, because the time required to complete the structure can be considerably reduced.

The present research paper aims at setting out a preliminary study of pop-up environments in order to provide recommendations for research, policies, and implementation for the realization 
of temporary strategies that allow an appropriate, healthy, and sustainable development of the city. The purpose of this study is not to imagine pop-up environments as replacements of traditional construction, but to suggest their use in the cases where modern urban planning fails to propose adequate solutions and where a temporary approach could be more appropriate.

Author Contributions: G.B. contributed mainly to the conceptualization, analysis, methodology and writing of the original draft; G.P. contributed mainly to review; T.F. contributed mainly to the validation, review and editing; G.L. contributed mainly to the funding acquisition, review and supervision; D.Ö. contributed mainly to the conceptualization, review, and editing.

Funding: This research was funded within the project "Urban Pop-Up Housing Environments and Their Potential as Local Innovation Systems" under the Vienna Science and Technology Fund (WWTF) with the project number ESR17-010.

Acknowledgments: Supported by the University of Natural Resources and Life Sciences, Vienna (BOKU) Open Access Publishing Fund.

Conflicts of Interest: The authors declare no conflict of interest.

\section{References and Note}

1. Fogel, R.W. Catching Up with the Economy. Am. Econ. Rev. 1999, 89, 1-21. [CrossRef]

2. Pompili, T. Networks within Cities and among Cities: A Paradigm for Urban Development and Governance. Proceeding of the ERSA Conference, Volos, Greece, 30 August-3 September 2006.

3. Marshall, S. City Planning, Design and Evolution Concepts. Routledge 2009, 1, $2-4$.

4. Taylor, N. Urban Planning Theory Since 1945; Sage: London, UK, 1998.

5. Mankus, M. Temporary Strategies. Volume 2015. Available online: http://volumeproject.org/temporarystrategies (accessed on 2 October 2019).

6. Smith, C. Jane Jacob's Guide to Urban Planning: Developing Baltimore City's Master Plan. 2009.

7. Mankus, M. Tactics for Temporary Uses of Buildings and Spaces in Architecture. Typology and Sociocultural Value. Sci. Future Lith. 2015, 7, 132-140. [CrossRef]

8. Lehtovuori, P.; Ruoppila, S. Temporary uses as means of experimental urban planning. Serb. Archit. J. 2012, 4, 29-54.

9. Oswalt, P.; Overmeyer, K.; Misselwitz, P. Urban Catalyst: The Power of Temporary Use; Dom Pub: Boston, MA, USA, 2013; ISBN 978-3-86922-261-5.

10. Matoga, A. How Media Shape the Perception of Temporary Uses. DisP Plan. Rev. 2019, 55, 85-96. [CrossRef]

11. Lehtovuori, P.; Ruoppila, S. Temporary uses producing difference in contemporary urbanism. In Transience and Permanence in Urban Development; Henneberry, J., Ed.; John Wiley-Blackwell: Hoboken, NJ, USA, 2017; pp. 47-63.

12. Urban Pop-Up Housing Environments and Their Potential as Local Innovation Systems. Available online: http://popupenvironments.boku.ac.at/ (accessed on 22 September 2019).

13. Madanayake, U. Sustainable implications of building reuse and adaption. In Proceedings of the 3rd World Construction Symposium 2014: Sustainability and Development in Built Environment, Colombo, Sri Lanka, 20-22 June 2014; University of Moratuwa: Moratuwa, Sri Lanka, 2014; pp. 139-158.

14. MacDonald, M.-P. Pop-Up Cities; ETC: New York, NY, USA, 2009; pp. 18-24.

15. Elrahman, A.S.A. Tactical Urbanism "A Pop-up Local Change for Cairo's Built Environment". Procedia Soc. Behav. Sci. 2016, 216, 224-235. [CrossRef]

16. Asefi, M.; Sirus, F.A. Transformable Shelter: Evaluation and New Architectural Design Proposals. Procedia Soc. Behav. Sci. 2012, 51, 961-966. [CrossRef]

17. Enshassi, A.; Kochendoerfer, B.; Rizq, E. An evaluation of environmental impacts of construction projects. Rev. Ing. Constr. 2014, 29, 234-254. [CrossRef]

18. Falasca, C.; Platania, M.; Donato, F. Architetture ad Assetto Variabile: Modelli Evolutivi per L'Habitat Provvisorio; Alinea: Firenze, Italy, 2000; ISBN 978-88-8125-377-7.

19. Langefors, L. Welcome Home, Please Leave Soon: Exploring Temporary Housing in the City of Stockholm; KTH Royal Institute of technology: Stockholm, Sweden, 2018.

20. Mengüşoğlu, N.; Boyacioğlu, E. Reuse of Industrial Built Heritage for Residential Purposes in Manchester. METU J. Fac. Archit. 2016, 30. 
21. Paparella, R.; Caini, M. Sistemi Modulari Abitativi Temporanei e Reimpiegabili ad Alta Efficienza Energetica; EdicomEdizioni: Monfalcone, Italy, 2017; Volume 1, ISBN 978-88-96386-58-3.

22. Singavi, A. Adaptive Reuse of Industrial Buildings; SMEF's Brick School of Architecture: Pune, India, 2018.

23. Wagemann, E. Need for Adaptation. Transformation of Temporary Houses. Disasters 2017, 41, 828-851. [CrossRef]

24. Horne, M. Temporary Use of Pop-Up Environment's Potential fpr Repuroisung Neglected Buildings and Spaces. Ph.D. Thesis, Georgia State University, Atlanta, Georgia, 2014.

25. Ursić, S.; Krnić, R.Č.M.; Mišetić, A. "Pop-up” Urban Allotment Gardens-How Temporary Urbanism Embraces the Garden Concept. Sociol. Prost. Časopis Istraživanje Prost. Sociokulturnog Razvoja 2018, 56, 53-69.

26. Brown, L.J.; Dixon, D.; Gillham, O. Urban Design for an Urban Century: Placemaking for People; Wiley: New York, NY, USA, 2009; ISBN 978-0-470-08782-4.

27. Panerai, P.; Castex, J.; Depaule, J.-C.; Samuels, I. Urban Forms: The Death and Life of the Urban Block; Routledge: New York, NY, USA, 2004; ISBN 978-0-7506-5607-8.

28. Portugali, J.; Stolk, E. Complexity, Cognition, Urban Planning and Design: Post-Proceedings of the 2nd Delft International Conference; Springer: Cham, Switzerland, 2016; ISBN 978-3-319-32653-5.

29. Piccinato, L.; Astengo, G. La Progettazione Urbanistica: La Città Come Organismo, 1st ed.; Marsilio Editori: Venezia, Italy, 1988; ISBN 978-88-317-5032-5.

30. Crawford, H.; Harriet, C. Sumer and the Sumerians; Cambridge University Press: Cambridge, UK, 2004; ISBN 978-0-521-53338-6.

31. Greco, E. La Città Greca Antica: Istituzioni, Società e Forme Urbane; Donzelli Editore: Roma, Italy, 1999; ISBN 978-88-7989-507-1.

32. Vitruvius Pollio. Vitruvius: Ten Books on Architecture; Rowland, I.D., Noble Howe, T., Eds.; Cambridge University Press: New York, NY, USA, 1999; ISBN 978-0-521-55364-3.

33. Amati, C. Dell'architettura di Marco Vitruvio Pollione; Giacomo Pirola ed.: Milano, Italy, 1829.

34. Haverfield, F. Ancient Town-Planning; Clarendon: Oxford, UK, 1913.

35. Fusaro, F. La Città Islamica; Laterza: Roma, Italy, 1984; ISBN 978-88-420-2493-4.

36. Petruccioli, A. Dar al Islam: Architetture del Territorio nei Paesi Islamici; Carucci: Roma, Italy, 1985; ISBN 978-88-85027-76-3.

37. Piccinato, L. Urbanistica Medievale; Dedalo libri: Venice, Italy, 1978.

38. Boerefijn, W.N.A. The Foundation, Planning and Building of New Towns in the 13th and 14th Centuries in Europe: An Architectural-Historical Research into Urban Form and Its Creation; Universiteit van Amsterdam: Amsterdam, The Netherlands, 2010; ISBN 978-90-90-25157-8.

39. Pantarotto, M. Il Giglio e la Croce Sulle Mura di Firenze. Semantic Scholar 2013. Available online: https://www.semanticscholar.org/paper/Il-giglio-e-la-croce-sulle-mura-di-Firenze-Pantarotto/ 9e89aa75ab66fec9e7525c114174538a134a539e\#paper-header (accessed on 5 October 2019).

40. Sciolla, G.C. La Città Ideale Nel Rinascimento; UTET: Torino, Italy, 1976.

41. Pavia, R. L'idea di Città. Teorie Urbanistiche Della Città Tradizionale; Franco Angeli: Milano, Italy, 1994; ISBN 978-88-204-8906-9.

42. Benevolo, L. Le Origini Dell'urbanistica Moderna; Laterza: Roma, Italy, 2003; ISBN 978-88-420-0205-5.

43. Homer, J.B. Theories of the Industrial Revolution: A Feedback Perspective. Dynamica 1982, 8 Pt 1, 30-35.

44. Hudson, P. The Industrial Revolution; Bloomsbury Academic: New York, NY, USA, 1992; ISBN 978-0-7131-6531-9.

45. Freestone, R. History of Urban Planning (Western). In International Encyclopedia of the Social E Behavioral Sciences, 2nd ed.; Wright, J.D., Ed.; Elsevier: Oxford, UK, 2015; pp. 862-868. ISBN 978-0-08-097087-5.

46. Bauman, Z. Liquid Times: Living in an Age of Uncertainty; Polity: Cambridge, UK, 2007; ISBN 978-0-7456-3987-1.

47. Perrucci, D.V.; Vazquez, B.A.; Aktas, C.B. Sustainable Temporary Housing: Global Trends and Outlook. Procedia Eng. 2016, 145, 327-332. [CrossRef]

48. Zhang, G.; Setunge, S.; van Elmpt, S. Using Shipping Containers to Provide Temporary Housing in Post-disaster Recovery: Social Case Studies. Procedia Econ. Financ. 2014, 18, 618-625. [CrossRef]

49. Hoerder, D.; Hoerder, D.V.P.D. Cultures in Contact: World Migrations in the Second Millennium; Duke University Press: Durham, UK, 2002; ISBN 978-0-8223-2834-6.

50. James, P.; Scerri, A.; Magee, L. Urban Sustainability in Theory and Practice: Circles of Sustainability; Routledge: New York, NY, USA, 2014. 
51. Cambridge Advanced Learner's Dictionary, 4th ed.; McIntosh, C. (Ed.) Cambridge University Press: Cambridge, UK, 2013; ISBN 978-1-107-68549-9.

52. POP-UP|Meaning in the Cambridge English Dictionary. Available online: https://dictionary.cambridge.org/ dictionary/english/pop-up (accessed on 9 October 2019).

53. Félix, D.; Branco, J.M.; Feio, A.O. Temporary housing after disasters: A state of the art survey. Habitat Int. 2013, 40, 136-141. [CrossRef]

54. Johnson, C. Impacts of prefabricated temporary housing after disasters: 1999 earthquakes in Turkey. Habitat Int. 2007, 31, 36-52. [CrossRef]

55. Arslan, H.; Cosgun, N. Reuse and recycle potentials of the temporary houses after occupancy: Example of Duzce, Turkey. Build. Environ. 2008, 43, 702-709. [CrossRef]

56. Arslan, H. Re-design, re-use and recycle of temporary houses. Build. Environ. 2007, 42, 400-406. [CrossRef]

57. Askar, R.; Rodrigues, A.L.; Bragança, L.; Pinheiro, D. From Temporary to Permanent. A Circular Approach for Post-disaster Housing Reconstruction. IOP Conf. Ser. Earth Environ. Sci. 2019, 225, 14. [CrossRef]

58. Atmaca, N. Life-cycle assessment of post-disaster temporary housing. Build. Res. Inf. 2017, 45, 524-538. [CrossRef]

59. Félix, D.; Monteiro, D.; Branco, J.M.; Bologna, R.; Feio, A. The role of temporary accommodation buildings for post-disaster housing reconstruction. J. Hous. Built Environ. 2015, 30, 683-699. [CrossRef]

60. Firrone, T. Sistemi Abitativi di Permanenza Temporanea; Aracne: Roma, Italy, 2007; ISBN 978-88-548-1037-2.

61. Hong, Y. A study on the condition of temporary housing following disasters: Focus on container housing. Front. Archit. Res. 2017, 6, 374-383. [CrossRef]

62. Ishii, T.; Ochi, S.; Tsubokura, M.; Kato, S.; Tetsuda, T.; Kato, J.; Nishikawa, Y.; Morita, T.; Kami, M.; Iwamoto, Y.; et al. Physical performance deterioration of temporary housing residents after the Great East Japan Earthquake. Prev. Med. Rep. 2015, 2, 916-919. [CrossRef] [PubMed]

63. Johnson, C. Strategic planning for post-disaster temporary housing. Disasters 2007, 31, 435-458. [CrossRef]

64. Johnson, C. Strategies for the Reuse of Temporary Housing. In Urban Transformation-Holcim Forum; University College London: London, UK, 2007.

65. McIntosh, J. The Implications of Post Disaster Recovery for Affordable Housing. In Approaches to Disaster Management_Examining the Implications of Hazards, Emergencies and Disasters; IntechOpen: Rijeka, Croatia, 2013.

66. Peacock, W.G. Post-Disaster Sheltering, Temporary Housing and Permanent Housing Recovery. In Handbook of Disaster Research; Springer: Cham, Switzerland, 2018.

67. Potangaroa, R. Sustainability by Design: The Challenge of Shelter in Post Disaster Reconstruction. Procedia Soc. Behav. Sci. 2015, 179, 212-221. [CrossRef]

68. Rizos, V.; Behrens, A.; van der Gaast, W.; Hofman, E.; Ioannou, A.; Kafyeke, T.; Flamos, A.; Rinaldi, R.; Papadelis, S.; Hirschnitz-Garbers, M.; et al. Implementation of Circular Economy Business Models by Small and Medium-Sized Enterprises (SMEs): Barriers and Enablers. Sustainability 2016, 8, 1212. [CrossRef]

69. Yang, J.; Yi, H. Research trends of post disaster reconstruction: The past and the future. Habitat Int. 2014, $42,21-29$.

70. Vallance, S.; Dupuis, A.; Thorns, D.; Edwards, S. Temporary use and the onto-politics of 'public' space. Cities 2017, 70, 83-90. [CrossRef]

71. de Smet, A. The role of temporary use in urban (re)development: Examples from Brussels. Bruss. Stud. 2013. [CrossRef]

72. Ferreri, M. The seductions of temporary urbanism. Ephemera 2015, 15, 181.

73. Fontes, A.S. Intervenções temporárias e marcas permanentes na cidade contemporânea. Arquitetura Rev. 2012, 8, 31-48. [CrossRef]

74. Haydn, F.; Temel, R. Temporäre Räume: Konzepte zur Stadtnutzung; Birkhäuser: Basel, Switzerland, 2006; ISBN 978-3-7643-7459-4.

75. Madanipour, A. Temporary use of space. Urban processes between flexibility, opportunity and precarity. Urban Stud. 2017, 55, 1093-1110. [CrossRef]

76. Nemeth, J.; Langhorst, J. Rethinking urban transformation: Temporary uses for vacant land. Cities 2014, 40, 143-150. [CrossRef]

77. Severinsen, C.A.; Howden-Chapman, P. The Problem and Politics of Temporary Housing. Hous. Theory Soc. 2014, 31, 125-147. [CrossRef] 
78. Tardiveau, A.; Mallo, D. Unpacking and Challenging Habitus: An Approach to Temporary Urbanism as a Socially Engaged Practice. J. Urban Des. 2014, 19, 456-472. [CrossRef]

79. Tumminia, G.; Guarino, F.; Longo, S.; Ferraro, M.; Cellura, M.; Antonucci, V. Life cycle energy performances and environmental impacts of a prefabricated building module. Renew. Sustain. Energy Rev. 2018, 92, $272-283$. [CrossRef]

80. Atmaca, A.; Atmaca, N. Comparative life cycle energy and cost analysis of post-disaster temporary housings. Appl. Energy 2016, 171, 429-443. [CrossRef]

81. Atmaca, A. Sustainable life span prediction of shelters constructed in refugee camps in Turkey. Energy Ecol. Environ. 2018, 3, 5-12. [CrossRef]

82. Rudkowski, J.; Heney, C.; Yu, H.; Sedlezky, S.; Gunn, F. Here Today, Gone Tomorrow? Mapping and modeling the pop-up retail customer journey. J. Retail. Consum. Serv. 2019. [CrossRef]

83. Scott, M.; Szili, G. Pop-up Polanyi: Cultural entrepreneurs and the 'vacancy fix'. City Cult. Soc. 2018, 14, 22-27. [CrossRef]

84. POP-UP RETAIL/Temporary Stores. Available online: https://trendwatching.com/trends/POPUP_RETAIL. htm (accessed on 10 October 2019).

85. Le Corbusier. Towards a New Architecture; Courier Corporation: New York, NY, USA, 1931; ISBN 978-0-486-25023-6.

86. Quaroni, L.; Quaroni, G.E. Progettare un Edificio. Otto Lezioni di Architettura; Kappa: Roma, Italy, 2001; ISBN 978-88-7890-412-5.

87. Everest, D. (2004). Cost model: Off-site manufacture. [online] Building. Available online: http://www. building.co.uk/cost-model-off-site-manufacture/3042466.article (accessed on 1 October 2019).

88. Rafi, M.M.; Nasir, M.M. Models for Prediction of 28-Day Concrete Compressive Strength. J. Test. Eval. 2016, 44, 1217-1228. [CrossRef]

89. Zuo, Z.; Gong, J.; Huang, Y.; Zhan, Y.; Gong, M.; Zhang, L. Experimental research on transition from scale 3D printing to full-size printing in construction. Constr. Build. Mater. 2019, 208, 350-360. [CrossRef]

90. Hager, I.; Golonka, A.; Putanowicz, R. 3D Printing of Buildings and Building Components as the Future of Sustainable Construction? Procedia Eng. 2016, 151, 292-299. [CrossRef]

91. Pasqualis, M.B. Case Temporanee. Strategie Innovative per L'emergenza Abitativa Post-Terremoto: Strategie Innovative per L'emergenza Abitativa Post-Terremoto; FrancoAngeli: Milano, Italy, 2014; ISBN 978-88-917-1744-3.

92. Holden, E.; Linnerud, K.; Banister, D. Sustainable development: Our Common Future revisited. Glob. Environ. Chang. 2014, 26, 130-139. [CrossRef]

93. McDonough, W.; Braungart, M. Cradle to Cradle: Remaking the Way We Make Things; Farrar, Straus and Giroux: New York, NY, USA, 2010; ISBN 978-1-4299-7384-7.

94. Directive 2010/31/EU of the European Parliament and of the Council of 19 May 2010 on the Energy Performance of Buildings; 2010; Vol. OJ L. 153, 13.

95. Torcellini, P.; Pless, S.; Deru, M.; Crawley, D. Zero Energy Buildings: A Critical Look at the Definition; NREL: Golden, CO, USA, 2006.

96. Miller, B. Spaces of Contention: Spatialities and Social Movements; Routledge: New York, NY, USA, 2016; ISBN 978-1-317-05176-3.

97. Tower Limite-Limite. Available online: http://beta.citymined.org/tower-limite-limite/ (accessed on 25 September 2019).

98. PROXY. Available online: http://proxysf.net/ (accessed on 12 July 2019).

99. Ein Platz für die Marie, Berlin-Pankow. Available online: http://www.stern-berlin.com/arbeitsfelder/ buergerbeteiligung/ein-platz-fuer-die-marie.html (accessed on 16 July 2019).

100. NLÉ. Available online: http://www.nleworks.com/ (accessed on 10 November 2019).

101. Nigeria's Makoko Floating School. Public Deliv. 2019. Available online: https://publicdelivery.org/makokofloating-school/ (accessed on 10 November 2019).

102. NDSM. Available online: https://www.ndsm.nl/en/ (accessed on 28 July 2019).

103. Haushalten, e.V. Available online: http://www.haushalten.org/ (accessed on 18 August 2019).

104. Temporiuso: Made in Mage. Available online: http://www.temporiuso.org/?page_id=1114 (accessed on 14 August 2019).

105. Add-On. Available online: http://www.add-on.at/index.html (accessed on 23 June 2019).

106. Christo \& Jeanne Claude Projects-The Gates. Available online: https://christojeanneclaude.net/projects/thegates (accessed on 8 June 2019). 
107. Shen Ting Tseng Architects. Available online: http://www.shentingtseng.com.tw/\#Page7 (accessed on 10 November 2019).

108. Floating Pavilion. Available online: https://www.shawnliustudio.com/floating (accessed on 10 November 2019).

109. Raumlabor Projects-Hovercraft. Available online: https://raumlabor.net/hovercraft-lifting-modernism/ (accessed on 5 December 2018). 